Article

\title{
Bifunctional Catalysis: Direct Reductive Amination of Aliphatic Ketones with an Iridium-Phosphate Catalyst ${ }^{\dagger}$
}

\section{Barbara Villa-Marcos ${ }^{1}$, Chaoqun Li ${ }^{1}$, Keith R. Mulholland ${ }^{2}$, Philip J. Hogan ${ }^{2}$ and Jianliang Xiao ${ }^{1, *}$}

1 Liverpool Centre for Materials and Catalysis, Department of Chemistry, University of Liverpool, Liverpool L69 7ZD, UK; E-Mail: barvm@liv.ac.uk (B.V.M.)

2 AstraZeneca, Silk Road Business Park, Macclesfield, SK10 2NA, UK

$\dagger$ Dedicated to the memory of Professor José M. Concellón.

* Author to whom correspondence should be addressed; E-Mail: jxiao@liv.ac.uk;

Tel.: +44-151-7942937; Fax: +44-151-7943588.

Received: 9 March 2010; in revised form: 29 March 2010 / Accepted: 2 April 2010 /

Published: 8 April 2010

\begin{abstract}
Chiral amines are one of the ubiquitous functional groups in fine chemical, pharmaceutical and agrochemical products, and the most convenient, economical, and ecobenign synthetic pathway to these amines is direct asymmetric reductive amination (DARA) of prochiral ketones. This paper shows that a wide range of aliphatic ketones can be directly aminated under hydrogenation conditions, affording chiral amines with good to excellent yields and with enantioselectivities up to $96 \%$ ee. The catalysis is effected by the cooperative action of a cationic $\mathrm{Cp} * \mathrm{Ir}(\mathrm{III})$ complex and its phosphate counteranion.
\end{abstract}

Keywords: reductive amination; asymmetric hydrogenation; bifunctional catalyst; aliphatic ketones; chiral amines

\section{Introduction}

The use of enantiomerically pure compounds has steadily increased in the pharmaceutical and agrochemical industry in the past decades. About $80 \%$ of all drug candidates in the pipeline are now chiral [1]. Chiral amines in particular are important intermediates in the pharmaceutical chemistry. Representative examples include rivastigmine, a drug for the treatment of Alzeihmer's [2], and 
repaglinide, which is used for the treatment of type II diabetes [3]. Tamsulosin, the blockbuster drug Flomax, can improve symptoms in patients with chronic prostatitis [4]. Additionally, chiral cyclic amines, such as the tetrahydro- $\beta$-carboline moiety frequently appear in natural products and biologically important molecules. For example, tubulosine displays high antitumor activity [5], and yohimbine is an antagonist for the serotonin 2B receptor [6] (Figure 1).

Figure 1. Examples of chiral amines in the pharmaceutical industry.<smiles>CCN(C)C(=O)Oc1cccc([C@@H](C)N(C)C)c1</smiles>

Rivastigmine<smiles>[R6][R6]O[Na]</smiles><smiles>CCOc1ccccc1OCCN[C@H](C)Cc1ccc(OC)c(S(N)(=O)=O)c1</smiles><smiles>CCCCCCCCCCCCC1NCCc2c1[nH]c1ccc(O)cc21</smiles><smiles>CCOC(=O)[C@@H]1[C@@H](O)CC[C@@H]2CN3CCc4c([nH]c5ccccc45)[C@H]3C[C@H]21</smiles>

Yohimbine

Asymmetric imine hydrogenation [7-16] and direct asymmetric reductive amination [17-19] (DARA) provide convenient methods for the synthesis of chiral amines. The latter is especially attractive from a commercial point of view, since one step is saved, avoiding the tedious isolation of usually-unstable imine intermediates. However, there are only a few efficient homogeneous metal catalysts reported for DARA [20-26], and not surprisingly, DARA still remains a key green chemistry research area [27]. In particular, the DARA of aliphatic ketones is relatively unexplored when compared to that of aromatic ketones.

The first enantioselective reductive amination was reported by Blaser in 1999 for the synthesis of (S)-metolachlor, the active ingredient of an important grass herbicide [20]. The product is obtained in a reasonable 78\% ee by the use of an Ir-xyliphos catalyst; but the scope of DARA has not been explored. Subsequently, Zhang and co-workers presented successful results for the DARA of aromatic ketones using an Ir-f-binaphane complex in the presence of $\mathrm{Ti}\left(\mathrm{O}^{i} \mathrm{Pr}\right)_{4}$ and $\mathrm{I}_{2}$ [21]. However, this catalyst did not work for DARA of aliphatic ketones. Chiral amino acids have been prepared by DARA of the corresponding keto-esters/-acids [25,26]. Börner et al. reported the DARA of $\alpha$-keto acids using a cationic Rh-Deguphos catalyst, affording good yields and up to 98\% ee [25]. Subsequently, Bunlaksananusorn and Rampf reported the synthesis of $\beta$-amino esters with a Ru-CIMeOBIPHEP catalyst, obtaining 70-88\% yields and excellent enantioselectivities (up to 99\%) [26]. Recently, RubioPérez et al. reported a successful catalyst for the DARA of aliphatic ketones [24]. The Pd-(R)-BINAP catalyst showed enantioselectivities up to $99 \%$; however, it failed to give satisfactory results with aromatic ketones, where the ee was only up to $43 \%$. 
Transfer hydrogenation has also been used to effect DARA. Kadyrov and co-workers reported the synthesis of primary amines by DARA. Using the $\left[\mathrm{Ru}((R)-\mathrm{TolBINAP}) \mathrm{Cl}_{2}\right]$ catalyst, excellent ee's were achieved in the DARA of aromatic ketones. In contrast, only a $24 \%$ ee was observed in the case of an aliphatic ketone [22]. Wills and co-workers reported an intramolecular reductive amination under transfer hydrogenation conditions with a Ru(II)TsDPEN catalyst, affording a cyclic amine in $88 \%$ ee [23]. Taken together, these results show that there is a need for more versatile catalysts for DARA, which are active, enantioselective, and effective for both aromatic and aliphatic ketones.

Recently, we became interested in the asymmetric reduction of imines [28-32]. Under hydrogenation conditions, we obtained excellent results for the enantioselective reduction of cyclic imines with a cationic Rh(III)-diamine catalyst (Scheme 1) [29]. Unfortunately, when applied to acyclic imines the same catalyst was not effective, affording only poor ee's.

Scheme 1. Hydrogenation of cyclic imines with a Rh(III)-chiral diamine catalyst.<smiles>[R]C1=[NH+]CCc2cc[R1]cc21</smiles><smiles>[R]C1NCCc2cc[R]cc21</smiles>
$[\mathrm{Rh}]=$

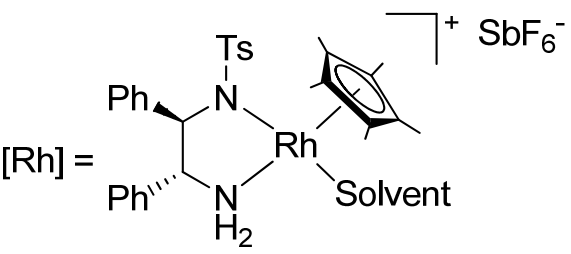

up to $99 \%$ ee

Previously, the groups of Macmillan [33], Rueping [34] and List [35] have shown that chiral phosphoric acid catalysts such as 3 (Figure 2) can induce excellent ee's in imine reduction and in DARA with Hantzsch esters, although the reaction times are generally long (up to 3 days). In these organocatalytic reactions, the phosphoric acid activates the imine via protonation and induces chirality by ion-pairing the resulting phosphate anion and iminium cation. Inspired by this work, we wondered whether a more versatile catalyst for DARA that uses $\mathrm{H}_{2}$ as the hydrogen could be constructed by the cooperative action of a $\mathrm{H}_{2}$-activating metal complex and a chiral phosphoric acid.

Figure 2. Catalyst $\mathbf{1}$ and phosphoric acids $\mathbf{2}$ and $\mathbf{3}$ used in this work.

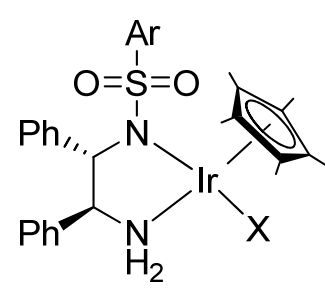

1

a: $\mathrm{Ar}=2,3,4,5,6-\left(\mathrm{CH}_{3}\right)_{5} \mathrm{C}_{6}$

b: $\mathrm{Ar}=2,4,6-\left(2-\mathrm{C}_{3} \mathrm{H}_{7}\right)_{3} \mathrm{C}_{6} \mathrm{H}_{2}$<smiles>O=P(O)(O)Oc1ccccc1-c1ccccc1</smiles>

2<smiles>[R]c1cc2ccccc2c(-c2c(OP(=O)(O)O)c([R])cc3ccccc23)c1O</smiles>

3

$\mathrm{R}=2,4,6-\left(2-\mathrm{C}_{3} \mathrm{H}_{7}\right)_{3} \mathrm{C}_{6} \mathrm{H}_{2}$

The key elements of the cooperative catalysis are illustrated in Scheme $2 . \mathrm{H}_{2}$ is activated by the metal complex and heterolytically cleaved, forming an iminium cation by imine protonation and an Irhydride complex. In a non-polar solvent, the iminium cation ion-pairs, via hydrogen bonding, with the chiral phosphate anion [33-35], and is reduced by hydride transfer from the metal complex 
(Scheme 2). The protonation activates the $\mathrm{C}=\mathrm{N}$ double bond towards attack by the hydride while ion pairing aids its enantiodiscrimination by the metal catalyst. This ionic hydrogenation pathway, which involves no coordination of the $\mathrm{C}=\mathrm{N}$ double bond to the metal, has previously been demonstrated by Norton by using iminium tetrafluoroborate salts [36,37].

We first demonstrated the synergistic effect of the metal-counteranion combination in the asymmetric hydrogenation of acyclic imines [28]. Encouraged by these results, we turned our attention to DARA, successfully extending the concept of cooperative catalysis to the reductive amination of both aromatic and aliphatic ketones [30]. Herein, we describe the details of our work on the DARA of aliphatic ketones.

Scheme 2. DARA of ketones via metal-counteranion cooperative catalysis.

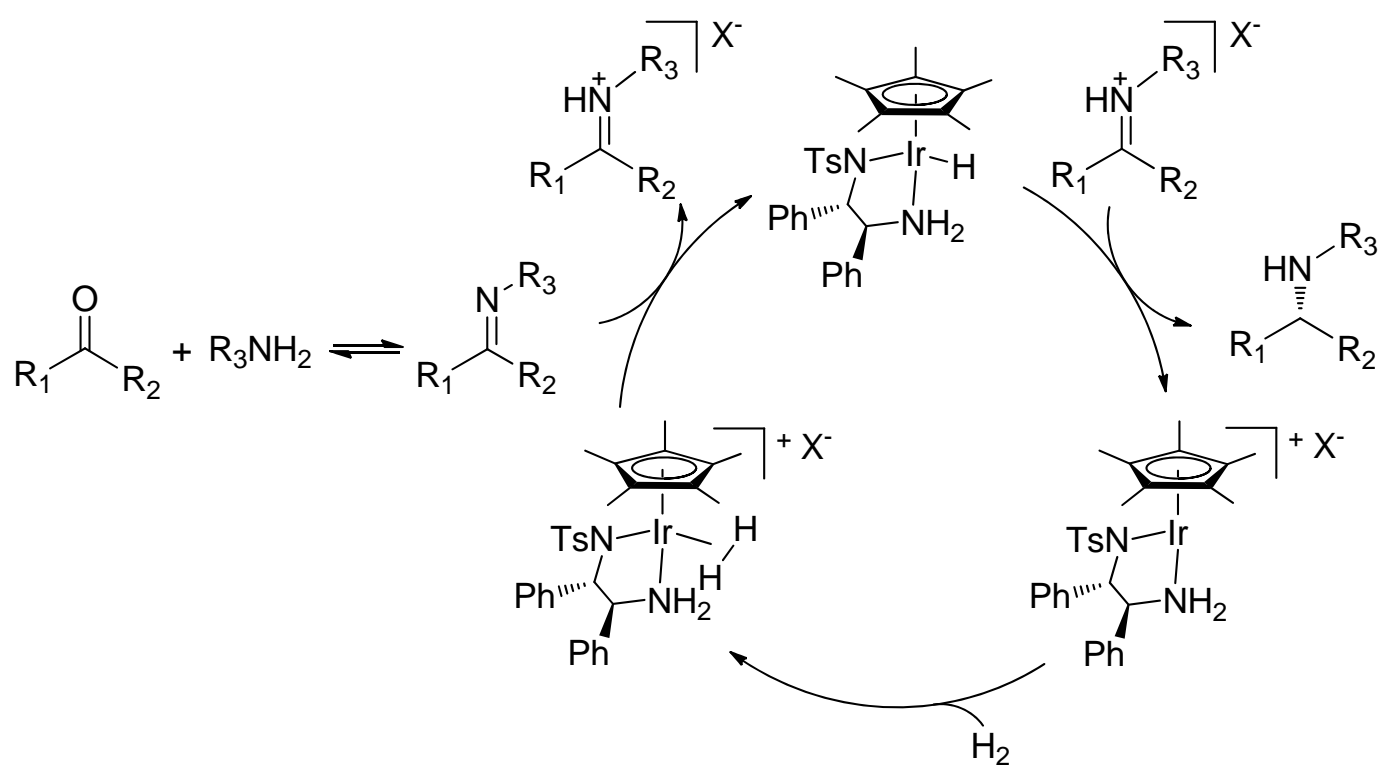

\section{Results and Discussion}

\subsection{Optimization of conditions}

We started with optimization of the DARA conditions by considering the model reaction of 4-methyl-pentan-2-one (4) with $p$-anisidine. Table 1 summarizes the results. While the complex 1a $(\mathrm{X}=\mathrm{Cl}$ ) (Figure 2) was inactive in the DARA of 4 (entry 1), exchange of the chloride for a noncoordinating counteranion such as $\mathrm{SbF}_{6}{ }^{-}$and $\mathrm{PF}_{6}{ }^{-}$allows the reaction to occur, but with low ee's (15 and 35\%, respectively; entries 2 and 3). Changing to the pseudo-chiral anion $2-\mathbf{H}$, the enantioselectivity rose to $47 \%$ (entry 4). This prompted us to search for an $\operatorname{Ir}(\mathrm{III})$-diamine complex containing a chiral counteranion. Thus, as reported before $[28,30]$, when we moved to the chiral phosphate 3-H, a 19\% conversion and a much higher ee of $84 \%$ were observed in $6 \mathrm{~h}$ reaction time (entry 6). Aiming to boost the conversion and ee, we then studied the effect of extra acid 3 and molecular sieves on the DARA. As can be seen, additional 3 indeed resulted in a faster reaction; but its effect on the enantioselectivity was less significant (entries 6 vs. 7-9). In a similar way, the presence of molecular sieves (MS) increased the reaction rate but not the enantioselectivity (entries 6 vs. 10-13). We presume that the presence of the MS benefits the ketimine formation by removal of water from the 
reaction media. Furthermore, we were pleased to discover that in the presence of the MS, the acid $\mathbf{3}$ is no longer critical to the DARA rate and ee (entry 12 vs. 16), an observation that is in contrast to what was observed in the DARA of aromatic ketones [30].

Table 1. Optimisation of conditions for the DARA of 4-methylpentan-2-one (4). ${ }^{\mathrm{a}}$

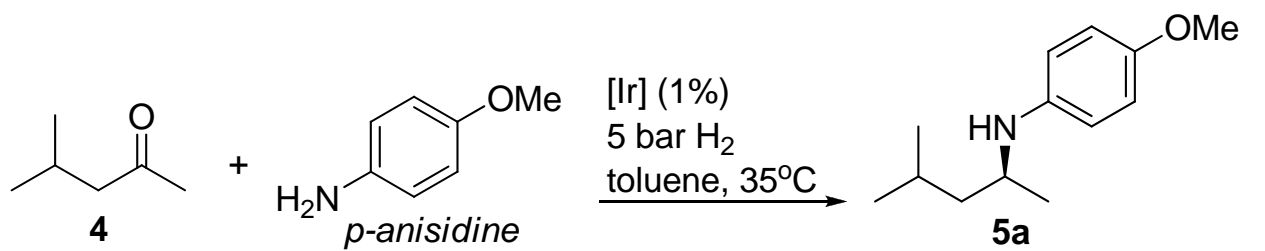

\begin{tabular}{|c|c|c|c|c|c|}
\hline Entry & Ar & $\mathbf{X}$ & Addtive & Conv. (\%) ${ }^{b}$ & $\operatorname{Ee}(\%)^{c}$ \\
\hline 1 & $\mathbf{a}$ & $\mathrm{Cl}$ & - & N.R. (17 h) & - \\
\hline 2 & $\mathbf{a}$ & $\mathrm{Cl}$ & $\operatorname{AgSbF}_{6}(2 \%)$ & $42(17 \mathrm{~h})$ & $15(R)$ \\
\hline 3 & $\mathbf{a}$ & $\mathrm{Cl}$ & $\operatorname{AgPF}_{6}(2 \%)$ & $60(17 \mathrm{~h})$ & $35(R)$ \\
\hline 4 & $\mathbf{a}$ & $2-\mathbf{H}$ & - & $11(17 \mathrm{~h})$ & $47(R)$ \\
\hline 5 & $\mathbf{a}$ & $2-H$ & $2(5 \%)$ & $28(17 \mathrm{~h})$ & $46(R)$ \\
\hline 6 & $\mathbf{a}$ & 3-H & - & 19 & $84(S)$ \\
\hline 7 & $\mathbf{a}$ & 3-H & $3(1 \%)$ & 42 & $85(S)$ \\
\hline 8 & $\mathbf{a}$ & 3-H & $3(5 \%)$ & 60 & $86(S)$ \\
\hline 9 & $\mathbf{a}$ & 3-H & $3(8 \%)$ & 67 & $89(S)$ \\
\hline 10 & $\mathbf{a}$ & 3-H & $4 \AA \mathrm{MS}(50 \mathrm{mg})$ & 30 & $85(S)$ \\
\hline 11 & $\mathbf{a}$ & 3-H & $4 \AA \mathrm{MS}(100 \mathrm{mg})$ & 50 & $86(S)$ \\
\hline 12 & $\mathbf{a}$ & 3-H & $4 \AA \mathrm{MS}$ & 59 & $86(S)$ \\
\hline 13 & $\mathbf{a}$ & 3-H & $4 \AA \mathrm{MS}(200 \mathrm{mg})$ & 59 & $86(S)$ \\
\hline 14 & $\mathbf{a}$ & 3-H & $3(1 \%), 4 \AA \mathrm{MS}$ & 58 & $85(S)$ \\
\hline $15^{\mathrm{d}}$ & $\mathbf{a}$ & 3-H & $3(5 \%), 4 \AA \mathrm{MS}$ & 63 & $86(S)$ \\
\hline 16 & $\mathbf{a}$ & 3-H & $3(8 \%), 4 \AA \mathrm{MS}$ & 72 & $86(S)$ \\
\hline 17 & $\mathbf{a}$ & 3-H & $4 \AA \mathrm{MS}$ & $57(24 \mathrm{~h})$ & $91(S)$ \\
\hline 18 & b & 3-H & - & 5 & - \\
\hline 19 & $\mathbf{b}$ & 3-H & $4 \AA \mathrm{MS}$ & 7 & - \\
\hline 20 & $\mathbf{b}$ & 3-H & $3(8 \%)$ & 50 & $71(S)$ \\
\hline 21 & $\mathbf{b}$ & 3-H & $3(8 \%), 4 \AA \mathrm{MS}$ & 60 & $74(S)$ \\
\hline 22 & $\mathbf{a}$ & 3-H & $4 \AA \mathrm{MS}$ & $>99(12 \mathrm{~h})$ & $87(S)$ \\
\hline
\end{tabular}

${ }^{a}$ Reaction conditions: $0.55 \mathrm{mmol}$ of $4,0.5 \mathrm{mmol}$ of $p$-anisidine, $1 \mathrm{~mol} \%$ of catalyst, $2 \mathrm{~mL}$ of toluene, 5 bar of $\mathrm{H}_{2}, 35^{\circ} \mathrm{C}, 150 \mathrm{mg}$ of $4 \AA$ MS when added unless specified, $6 \mathrm{~h}$ unless specified.

${ }^{\mathrm{b}}$ Conversion of $p$-anisidine, determined by ${ }^{1} \mathrm{H}$-NMR analysis of the crude product. ${ }^{\mathrm{c}}$ Determined by HPLC analysis; ${ }^{\mathrm{d}} 20^{\circ} \mathrm{C}$.

The observations above point to an easier ketimine formation in the DARA of aliphatic ketones. In the case of aromatic ketones, the reaction appears to be limited by this step and hence necessitates both a Brønsted acid and MS, which can catalyze the ketone-amine condensation and help shift the resulting equilibrium by removing water [28,30]. Scheme 3 illustrates a competition reaction between an aromatic and an aliphatic ketone, which led to the predominant DARA of 4, showing that aromatic ketones are essentially inactive under the questions employed. When dealing 
with the aliphatic ketones, we also noted that there was no competition between hydrogenation of ketones over imines; the ketones were not reduced under the DARA conditions.

Scheme 3. Competitive DARA of an aromatic and an aliphatic ketone with $p$-anisidine.

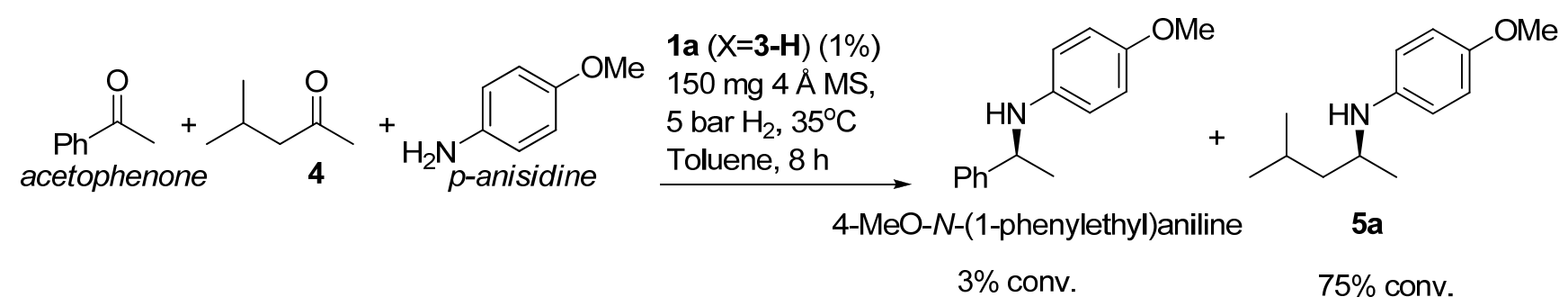

A quick screening on the ligand showed that catalyst $\mathbf{1 a}(X=3-\mathbf{H})$ surpassed $\mathbf{1 b}(\mathrm{X}=\mathbf{3}-\mathbf{H})$ in terms of activity and enantioselectivity (entry 16 vs. 21). In addition, the effect of temperature was also studied. Although a slight increase in the enantioselectivity was observed (entry 17), lowering the temperature to $20^{\circ} \mathrm{C}$ afforded only a $57 \%$ conversion after $24 \mathrm{~h}$. Finally, we confirmed the reaction goes to completion in $12 \mathrm{~h}$ reaction time (entry 22). Taken together, these results suggest the optimum reaction conditions to include catalyst $\mathbf{1 a}(\mathrm{X}=\mathbf{3}-\mathbf{H})$ and $\mathrm{MS}(150 \mathrm{mg})$, and we deemed the addition of extra 3 unnecessary, avoiding the use of an expensive chiral acid.

\subsection{Scope of substrates}

Next, we explored the application of the optimized reaction conditions to a variety of aliphatic ketones and aromatic amines. As can be seen, a wide range of aliphatic ketones were readily aminated with $p$-anisidine (Table 2 ), $m$-anisidine (Table 3 ) and relatively more electron-deficient anilines (Table 4) under 5 bar of $\mathrm{H}_{2}$ at $35{ }^{\circ} \mathrm{C}$. The amines 5,6 and 7 were obtained with good yields and excellent enantioselectivities in general. Notably, the catalyst tolerates other reducible functional groups in the substrates, such as terminal (5i) and internal alkenes $(\mathbf{5 j}, \mathbf{6 h}, \mathbf{7 e})$ and highly strained cyclopropyl ring $(5 \mathbf{h}, \mathbf{6 i}, \mathbf{7 f})$.

Table 2 presents the results for the DARA with $p$-anisidine. Compared to our results reported for imine hydrogenation at $20^{\circ} \mathrm{C}(5 \mathbf{a}, 5 \mathbf{e}, 5 \mathbf{i})$ [28], the enantioselectivity is slightly lower, but with the advantage of not isolating the imines. The product $5 \mathbf{c}$ was previously obtained in $84 \%$ ee [38], via the reduction of the corresponding enantiomerically pure $\alpha$-sulfinyl ketimine followed by desulfinylation. 5e appeared in the DARA with the Pd- $(R)$-BINAP, showing a slightly lower ee (76\%) [24]. The amine 5i was obtained by Macmillan et al. in $90 \%$ ee in DARA with Hanztsch ester, but requiring a long reaction time $(96 \mathrm{~h})$ [33]. Finally, the amine $5 \mathbf{j}$ has also been reported, as the product of the hydrosilylation of the corresponding imine with $90 \%$ ee [39].

In general, the products arising from the DARA of alkyl-methyl ketones with $p$-anisidine are obtained with good yields and excellent ee's. However, the enantioselectivity dropped significantly when alkyl-ethyl ketones were aminated (5f, 5g). Clearly, the catalyst is unable to discriminate efficiently an ethyl from a butyl or pentyl group. 
Table 2. DARA of aliphatic ketones with $p$-anisidine. ${ }^{\text {a }}$

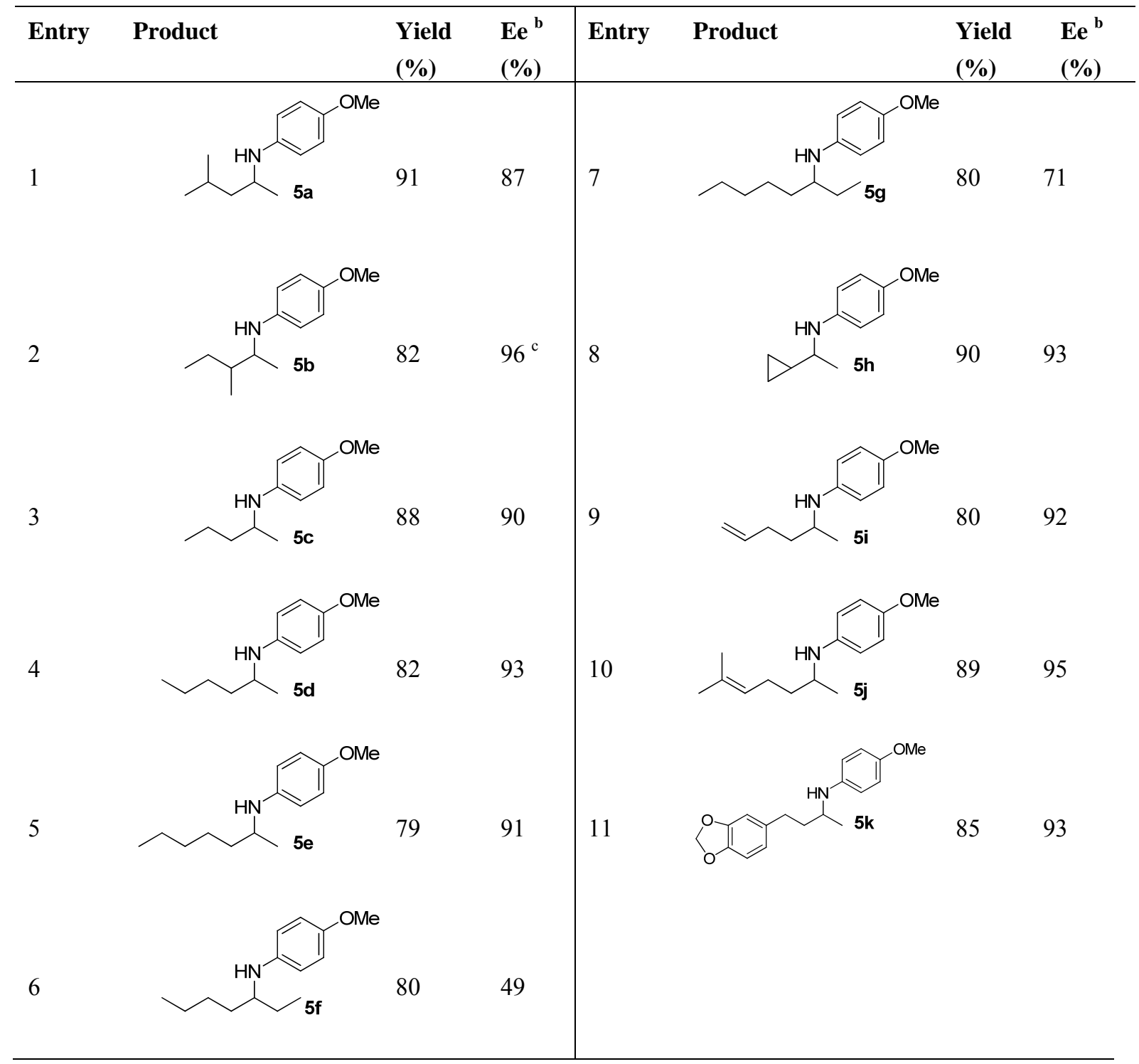

\footnotetext{
${ }^{a}$ Reaction conditions: $0.55 \mathrm{mmol}$ of ketone, $0.5 \mathrm{mmol}$ of $p$-anisidine, $1 \mathrm{~mol} \%$ of $1 \mathrm{a}(\mathrm{X}=3-\mathrm{H})$, $2 \mathrm{~mL}$ of toluene, $150 \mathrm{mg}$ of $4 \AA \mathrm{MS}, 5$ bar of $\mathrm{H}_{2}, 35{ }^{\circ} \mathrm{C}, 12-20 \mathrm{~h} .{ }^{\mathrm{b}}$ Determined by HPLC; $S$ configuration, assigned by comparison with the literature [33]. ${ }^{\mathrm{c}} \sim 2 \%$ d.e.
}

With the sterically more demanding $m$-methoxyanilines, both the yields and ee's remained good, although lower than those with $p$-anisidines in most cases (Table 3). This lowering in ee may stem from a less favored interaction of the iminium ion with either the metal catalyst or the counteranion or both. Worthy of particular mention is the amine 6c, where the catalyst is capable of differentiating an isopropyl and a methyl group, affording an excellent $90 \%$ ee. The amines $6 \mathbf{e}, \mathbf{6 h}$ and $\mathbf{6 i}$ have been previously reported as products for a tandem intermolecular hydroamination-transfer hydrogenation of alkynes [40]. Although similar enantioselectivities were achieved, much longer reaction times appear to be necessary (up to $72 \mathrm{~h}$ ). As in the case of $p$-anisidines, the enantioselectivity dropped significantly when alkyl-ethyl ketones were used (6f and $\mathbf{6 g})$. 
Table 3. DARA with $m$-substituted anilines. ${ }^{\text {a }}$

\begin{tabular}{|c|c|c|c|c|c|c|c|}
\hline Entry & Product & $\begin{array}{l}\text { Yield } \\
(\%)\end{array}$ & $\begin{array}{l}\text { Ee } \\
(\%)\end{array}$ & Entry & Product & $\begin{array}{l}\text { Yield } \\
\text { (\%) }\end{array}$ & $\begin{array}{l}\text { Ee } \\
(\%)\end{array}$ \\
\hline 1 & & 72 & 80 & 6 & & 81 & 61 \\
\hline 2 & & 82 & $96^{b}$ & 7 & & 83 & 64 \\
\hline 3 & & 86 & 90 & 8 & & 67 & 82 \\
\hline 4 & & 77 & 91 & 9 & & 62 & 82 \\
\hline 5 & & 85 & 92 & 10 & & 80 & 91 \\
\hline
\end{tabular}

${ }^{\mathrm{a}}$ Reaction conditions were the same as those in Table 2, except with $0.5 \mathrm{mmol} \mathrm{m}$-anisidine. ${ }^{\mathrm{b}} \sim 8 \%$ d.e.

We then investigated DARA of aliphatic ketones with aniline and more electron-deficient analogues. Amines 7 were obtained with good yields and enantioselectivities (Table 4). Of particular note is that 4-bromo aniline also reacted, giving rise to a decent yield and ee, albeit in a longer reaction time (7h). Other aliphatic ketones were also aminated with 4-bromo as well as 4-chloro-aniline, affording $70-90 \%$ yields. However, we have not been able to find suitable conditions to separate the enantiomers by HPLC; so they are not included in this paper. Compounds $\mathbf{7 a}$ and $\mathbf{7 b}$ were previously obtained in DARA with the $\left[\operatorname{PdBr}_{2}((R)\right.$-BINAP)] catalyst [24], with only a $51 \%$ and $10 \%$ ee, respectively. A poor ee (17\%) was also observed for the amine $7 \mathbf{b}$ in the hydrogenation of the corresponding imine with a cationic $\operatorname{Ir}(\mathrm{I})$ complex containing a chiral phosphanodihydrooxazole ligand [41]. Similarly, the amine 7d was previously obtained in only $18 \%$ ee in the literature [42]. The current catalytic system does not work with aliphatic amines, however, where the intermediate imine is formed but not reduced. 
Table 4. DARA with aniline and 4-bromoaniline. ${ }^{\mathrm{a}}$

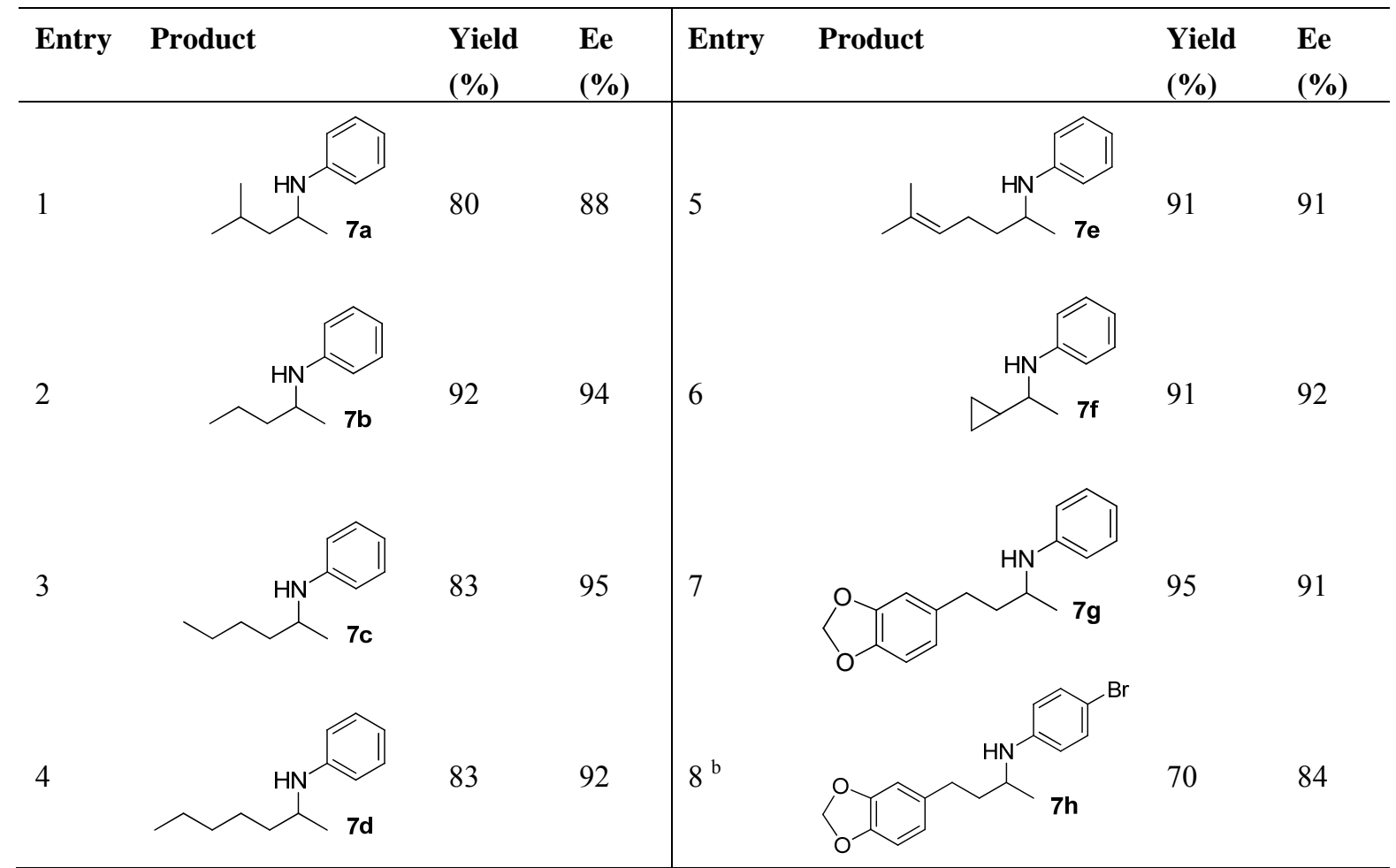

${ }^{a}$ Same conditions as those in Table 2, except with $0.5 \mathrm{mmol}$ aniline. ${ }^{\mathrm{b}} 0.5 \mathrm{mmol}$ 4-bromoaniline, $30 \mathrm{~h}$.

To further appreciate how steric effects affect the cooperative DARA, we compared the amination of the ketones in Figure 3 with $p$-anisidine. As can be seen, with increasing steric hindrance near the carbonyl carbon, the DARA becomes slower, and no amination was observed with the sterically most demanding tert-butylmethyl ketone, even after $24 \mathrm{~h}$. This reduction in rate is most likely a result of increased difficulty in hydride transfer. The enantioselectivity is, however, more subtle to explain, as it does not follow the trend of reaction rate and is highest with a sterically bulky ketone (entries 2 vs. 1 and 3, Table 2). This is probably a reflection of the enantioselectivity being controlled by both the Ir(III) catalyst and its counteranion. The former is responsible for hydride delivery and would be expected to respond to steric effects in the manner observed.

Figure 3. Conversions observed in the DARA with 1a $(\mathrm{X}=3-\mathbf{H})(1 \%)$ at 5 bar $\mathrm{H}_{2}$ and $35^{\circ} \mathrm{C}$ in $8 \mathrm{~h}$.

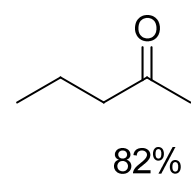<smiles>CC(=O)CC(C)C</smiles><smiles>CCC(CC)C(C)=O</smiles><smiles>[R]NC(C)(C)C(C)=O</smiles>

\section{Experimental}

\subsection{General}

Unless otherwise specified, the chemicals were obtained commercially and used without further purification. Toluene was dried over sodium and distilled prior to use. $4 \AA$ molecular sieves (MS) were 
dried in an oven at $160{ }^{\circ} \mathrm{C}$ for a minimum of $24 \mathrm{~h}$. NMR spectra were recorded on a DRX-400 spectrometer operating at $400 \mathrm{MHz}\left({ }^{1} \mathrm{H}\right)$ or $100 \mathrm{Mhz}\left({ }^{13} \mathrm{C}\right)$ using $\mathrm{CDCl}_{3}$ as solvent and TMS as the internal standard. The mass spectra were obtained by chemical ionization (CI). HPLC analysis was performed on a Gilson UV/VIS-151 equipped with an OD-H, OB-H or OJ column purchased from Daicel Chemical Industries. The catalysts $\mathbf{1 a}(\mathrm{X}=\mathbf{2}-\mathbf{H}), \mathbf{1 a}(\mathrm{X}=\mathbf{3}-\mathbf{H})$ and $\mathbf{1 b}(\mathrm{X}=\mathbf{3}-\mathbf{H})$ were synthesized according to the literature procedure by reacting the corresponding $16 \mathrm{e}^{-}$species with the phosphoric acid $\mathbf{2}$ or $\mathbf{3}$, without further purification [28,43]. Compounds $\mathbf{2}$ and $\mathbf{3}$ were also prepared following the literature procedure [33,35], as well as catalyst $\mathbf{1 a}(\mathrm{X}=\mathrm{Cl})$ [44]. The configuration of $\mathbf{5 i}$ was assigned by comparison with the literature [33], and that of the rest was based on analogy with the assignment for that compound without verification.

\subsection{General procedure for DARA}

To a glass liner equipped with a stir bar was added $4 \AA \mathrm{MS}(150 \mathrm{mg})$, aliphatic ketone $(0.55 \mathrm{mmol})$, amine $(0.5 \mathrm{mmol})$, catalyst $(5 \mu \mathrm{mol})$ and distilled toluene $(2 \mathrm{~mL})$. The glass liner was then placed into an autoclave, followed by degassing with $\mathrm{H}_{2}$ three times. The hydrogenation was carried out at 5 bar $\mathrm{H}_{2}$ with stirring at $35^{\circ} \mathrm{C}$ for $12-30 \mathrm{~h}$. The hydrogen gas was then carefully released in a fume hood and the solution was filtered, transferred to a flask, and concentrated to afford the crude product. Flash chromatography purification with a column of silica gel eluted with petroleum ether/ethyl acetate $(15 / 1)$ yielded the desired amine product.

4-Methoxy-N-(4-methylpentan-2-yl)aniline (5a) [28]. The product (94 mg, 91\% yield, 87\% ee) was obtained according to the general procedure from 4-methylpentan-2-one (55 $\mathrm{mg}, 0.55 \mathrm{mmol})$ and $p$ anisidine (62 mg, $0.5 \mathrm{mmol})$ in $12 \mathrm{~h}$; ${ }^{1} \mathrm{H}-\mathrm{NMR}$ : $\delta 0.83(\mathrm{~d}, J=6.6 \mathrm{~Hz}, 3 \mathrm{H}), 0.85(\mathrm{~d}, J=6.6 \mathrm{~Hz}, 3 \mathrm{H})$, $1.05(\mathrm{~d}, J=6.3 \mathrm{~Hz}, 3 \mathrm{H}), 1.15(\mathrm{dt}, J=13.7,6.9 \mathrm{~Hz}, 1 \mathrm{H}), 1.37$ (dt, $J=13.7,6.9 \mathrm{~Hz}, 1 \mathrm{H}), 1.62-1.72(\mathrm{~m}$, 1H), 2.92 (brs, $1 \mathrm{H}), 3.31-3.39(\mathrm{~m}, 1 \mathrm{H}), 3.66(\mathrm{~s}, 3 \mathrm{H}), 6.45-6.49(\mathrm{~m}, 2 \mathrm{H}), 6.67-6.71(\mathrm{~m}, 2 \mathrm{H})$; ${ }^{13} \mathrm{C}-\mathrm{NMR}$ : $\delta 21.5,22.9,23.4,25.5,47.4,48.0,56.2,115.1,115.4,142.3,152.2$; HRMS for $\mathrm{C}_{13} \mathrm{H}_{22} \mathrm{NO}[\mathrm{M}+\mathrm{H}]^{+}$: $\mathrm{m} / \mathrm{z}$ Calcd: 208.1701; Found: 208.1705; HPLC (Chiralcel OD-H, hexane:isopropanol = 99:1, flow rate $0.5 \mathrm{~mL} / \mathrm{min}, \lambda=254 \mathrm{~nm}$ ): $\mathrm{t}_{\mathrm{R}}=13.5 \mathrm{~min}$ (minor), $\mathrm{t}_{\mathrm{R}}=14.6 \mathrm{~min}$ (major).

4-Methoxy-N-(3-methylpentan-2-yl)aniline (5b). Mixture of diastereoisomers 51:49. The product ( $85 \mathrm{mg}, 82 \%$ yield, 96\% ee) was obtained according the general procedure from 3-methylpentan-2-one (55 mg, $0.55 \mathrm{mmol})$ and $p$-anisidine $(62 \mathrm{mg}, 0.5 \mathrm{mmol})$ in $20 \mathrm{~h} ;{ }^{1} \mathrm{H}-\mathrm{NMR}: \delta 0.84-0.94(\mathrm{~m}, 6 \mathrm{H}), 1.03$ $(\mathrm{d}, J=8.6 \mathrm{~Hz}, 1.5 \mathrm{H}), 1.07(\mathrm{~d}, J=7.6 \mathrm{~Hz}, 1.5 \mathrm{H}), 1.13-1.25(\mathrm{~m}, 1 \mathrm{H}), 1.42-1.63(\mathrm{~m}, 2 \mathrm{H}), 3.31-3.40(\mathrm{~m}$, $1 \mathrm{H}), 3.74(\mathrm{~s}, 3 \mathrm{H}), 6.55-6.58(\mathrm{~m}, 2 \mathrm{H}), 6.74-6.78(\mathrm{~m}, 2 \mathrm{H})$; ${ }^{13} \mathrm{C}-\mathrm{NMR}: \delta 12.3(7), 12.4(3), 14.0,15.7$, 16.0, 17.6, 25.2, 27.0, 38.6, 39.5, 53.5, 54.1, 56.2, 115.2, 115.4, 142.5, 152.2; HRMS for $\mathrm{C}_{13} \mathrm{H}_{22} \mathrm{NO}$ [M+H] $]^{+}: \mathrm{m} / \mathrm{z}$ Calcd: 208.1701; Found: 208.1697; HPLC (Chiralcel OD-H, hexane:isopropanol = 99:1, flow rate $0.5 \mathrm{~mL} / \mathrm{min}, \lambda=254 \mathrm{~nm})$ : $t_{\mathrm{R}}=12.0 \mathrm{~min}(\mathrm{~d} 1, \operatorname{minor}), \mathrm{t}_{\mathrm{R}}=12.9 \min (\mathrm{d} 2, \operatorname{minor}), \mathrm{t}_{\mathrm{R}}=13.8(\mathrm{~d} 1$, major $), t_{R}=14.8(\mathrm{~d} 2$, major $)$.

4-Methoxy-N-(pentan-2-yl)aniline (5c) [38]. The product ( $85 \mathrm{mg}, 88 \%$ yield, $90 \%$ ee) was obtained according to the general procedure from 2-pentanone ( $47 \mathrm{mg}, 0.55 \mathrm{mmol})$ and $p$-anisidine $(62 \mathrm{mg}, 0.5 \mathrm{mmol})$ 
in $20 \mathrm{~h} ;{ }^{1} \mathrm{H}-\mathrm{NMR}: \delta 0.92(\mathrm{t}, J=7.1 \mathrm{~Hz}, 3 \mathrm{H}), 1.14(\mathrm{~d}, J=6.3 \mathrm{~Hz}, 3 \mathrm{H}), 1.33-1.45(\mathrm{~m}, 3 \mathrm{H}), 1.50-1.57$ (m, 1H), 3.11 (brs, 1H), 3.38 (sextet, $J=6.3 \mathrm{~Hz}, 1 \mathrm{H}), 3.74$ (s, 3H), 6.53-6.57 (m, 2H), 6.75-6.79 (m, $2 \mathrm{H}) ;{ }^{13} \mathrm{C}-\mathrm{NMR} \delta 14.6,19.8,21.2,39.9,49.6,56.2,115.1,115.4,142.4,152.2$; HRMS for $\mathrm{C}_{12} \mathrm{H}_{20} \mathrm{NO}$ $[\mathrm{M}+\mathrm{H}]^{+}: \mathrm{m} / \mathrm{z}$ Calcd: 194.1545; Found: 194.1539; HPLC (Chiralcel OD-H, hexane:isopropanol = 99:1, flow rate $0.5 \mathrm{~mL} / \mathrm{min}, \lambda=254 \mathrm{~nm}$ ): $t_{\mathrm{R}}=15.1 \mathrm{~min}$ (minor), $\mathrm{t}_{\mathrm{R}}=15.8 \mathrm{~min}$ (major).

4-Methoxy-N-(hexan-2-yl)aniline (5d) [45]. The product ( $85 \mathrm{mg}, 82 \%$ yield, 93\% ee) was obtained according to the general procedure from 2-hexanone ( $55 \mathrm{mg}, 0.55 \mathrm{mmol})$ and $p$-anisidine $(62 \mathrm{mg}, 0.5 \mathrm{mmol})$ in $20 \mathrm{~h}$; ${ }^{1} \mathrm{H}-\mathrm{NMR}$ : $\delta 0.90(\mathrm{t}, J=7.1 \mathrm{~Hz}, 3 \mathrm{H}), 1.15(\mathrm{~d}, J=6.3 \mathrm{~Hz}, 3 \mathrm{H}), 1.30-1.42(\mathrm{~m}, 5 \mathrm{H}), 1.53-1.59$ (m, 1H), 3.36 (sextet, $J=6.3 \mathrm{~Hz}, 1 \mathrm{H}), 3.74(\mathrm{~s}, 3 \mathrm{H}), 6.53-6.57(\mathrm{~m}, 2 \mathrm{H}), 6.75-6.79(\mathrm{~m}, 2 \mathrm{H})$; ${ }^{13} \mathrm{C}-\mathrm{NMR}$ : $\delta 14.5,21.2,23.2,28.8,37.4,49.9,56.3,115.1,115.4,142.5,152.2$; HRMS for $\mathrm{C}_{13} \mathrm{H}_{22} \mathrm{NO}[\mathrm{M}+\mathrm{H}]^{+}$: m/z Calcd: 208.1701; Found: 208.1705; HPLC (Chiralcel OD-H, hexane:isopropanol = 99:1, flow rate $0.5 \mathrm{~mL} / \mathrm{min}, \lambda=254 \mathrm{~nm}$ ): $\mathrm{t}_{\mathrm{R}}=14.1 \mathrm{~min}$ (minor), $\mathrm{t}_{\mathrm{R}}=14.7 \mathrm{~min}$ (major).

$\mathrm{N}$-(Heptan-2-yl)-4-methoxyaniline (5e) [24,28]. The product ( $87 \mathrm{mg}, 79 \%$ yield, 91\% ee) was obtained according to the general procedure from 2-heptanone $(63 \mathrm{mg}, 0.55 \mathrm{mmol})$ and $p$-anisidine $(62 \mathrm{mg}, 0.5 \mathrm{mmol})$ in $20 \mathrm{~h} ;{ }^{1} \mathrm{H}-\mathrm{NMR}$ : $\delta 0.89(\mathrm{t}, J=6.8 \mathrm{~Hz}, 3 \mathrm{H}), 1.14(\mathrm{~d}, J=6.3 \mathrm{~Hz}, 3 \mathrm{H}), 1.24-1.32(\mathrm{~m}, 4 \mathrm{H}), 1.34-1.43$ (m, 3H), 1.50-1.59 (m, 1H), 3.12 (brs, 1H), 3.32-3.39 (m, 1H), $3.74(\mathrm{~s}, 3 \mathrm{H}), 6.53-6.57(\mathrm{~m}, 2 \mathrm{H})$, 6.75-6.79 (m, 2H); ${ }^{13} \mathrm{C}-\mathrm{NMR}: \delta 14.4,21.2,23.1,26.3,32.3,37.6,50.0,56.3,115.1,115.4,142.4$, 152.3; HRMS for $\mathrm{C}_{14} \mathrm{H}_{24} \mathrm{NO}[\mathrm{M}+\mathrm{H}]^{+}: \mathrm{m} / \mathrm{z}$ Calcd: 222.1858; Found: 222.1852; HPLC (Chiralcel OB$\mathrm{H}$, hexane:isopropanol $=99: 1$, flow rate $1.0 \mathrm{~mL} / \mathrm{min}, \lambda=254 \mathrm{~nm}$ ): $\mathrm{t}_{\mathrm{R}}=9.3 \mathrm{~min}$ (major), $\mathrm{t}_{\mathrm{R}}=10.6 \min$ (minor).

$\mathrm{N}$-(Heptan-3-yl)-4-methoxyaniline (5f). The product (105 mg, 95\% yield, 49\% ee) was obtained according to the general procedure from 3-heptanone $(63 \mathrm{mg}, 0.55 \mathrm{mmol})$ and $p$-anisidine $(62 \mathrm{mg}, 0.5 \mathrm{mmol})$ in $20 \mathrm{~h}$; ${ }^{1} \mathrm{H}-\mathrm{NMR}$ : $\delta 0.89(\mathrm{t}, J=7.1 \mathrm{~Hz}, 3 \mathrm{H}), 0.91(\mathrm{t}, J=7.5 \mathrm{~Hz}, 3 \mathrm{H}), 1.26-1.59(\mathrm{~m}, 8 \mathrm{H}), 3.18$ (quintet, $J=6.0 \mathrm{~Hz}, 1 \mathrm{H}), 3.74(\mathrm{~s}, 3 \mathrm{H}), 6.52-6.56(\mathrm{~m}, 2 \mathrm{H}), 6.74-6.78(\mathrm{~m}, 2 \mathrm{H}) ;{ }^{13} \mathrm{C}-\mathrm{NMR} \delta 10.4,14.5,23.3$, 27.5, 28.6, 34.4, 55.5, 56.3, 114.7, 115.4, 142.9, 151.9; HRMS for $\mathrm{C}_{14} \mathrm{H}_{24} \mathrm{NO}[\mathrm{M}+\mathrm{H}]^{+}: \mathrm{m} / \mathrm{z}$ Calcd: 222.1858; Found: 222.1850; HPLC (Chiralcel OB-H, hexane:isopropanol $=99: 1$, flow rate 0.5 $\mathrm{mL} / \mathrm{min}, \lambda=254 \mathrm{~nm}$ ): $\mathrm{t}_{\mathrm{R}}=14.0 \mathrm{~min}$ (major), $\mathrm{t}_{\mathrm{R}}=15.8 \mathrm{~min}$ (minor).

4-Methoxy-N-(octan-3-yl)aniline (5g). The product (94 $\mathrm{mg}, 80 \%$ yield, $71 \%$ ee) was obtained according to the general procedure from 3-octanone $(71 \mathrm{mg}, 0.55 \mathrm{mmol})$ and $p$-anisidine $(62 \mathrm{mg}, 0.5 \mathrm{mmol})$ in $20 \mathrm{~h}$; ${ }^{1} \mathrm{H}-\mathrm{NMR}: \delta 0.86-0.93(\mathrm{~m}, 6 \mathrm{H}), 1.27-1.59(\mathrm{~m}, 10 \mathrm{H}), 3.14$ (brs, $\left.1 \mathrm{H}\right), 3.18$ (quintet, $J=5.9 \mathrm{~Hz}, 1 \mathrm{H}$ ), $3.74(\mathrm{~s}, 3 \mathrm{H}), 6.54(\mathrm{~d}, J=8.8 \mathrm{~Hz}, 2 \mathrm{H}), 6.76(\mathrm{~d}, J=8.8 \mathrm{~Hz}, 2 \mathrm{H}) ;{ }^{13} \mathrm{C}-\mathrm{NMR}: \delta 10.4,14.5,23.1,26.1$, 27.5, 32.5, 34.7, 55.5, 56.3, 114.7, 115.3, 142.9, 151.9; HRMS for $\mathrm{C}_{15} \mathrm{H}_{26} \mathrm{NO}[\mathrm{M}+\mathrm{H}]^{+}: \mathrm{m} / \mathrm{z}$ Calcd: 236.2009; Found: 236.2006; HPLC (Chiralcel OB-H, hexane:isopropanol $=99: 1$, flow rate $1.0 \mathrm{~mL} / \mathrm{min}, \lambda=254 \mathrm{~nm}$ ): $\mathrm{t}_{\mathrm{R}}=11.0 \mathrm{~min}$ (major), $\mathrm{t}_{\mathrm{R}}=13.6 \mathrm{~min}$ (minor).

$\mathrm{N}$-(1-Cyclopropylethyl)-4-methoxyaniline (5h). The product ( $86 \mathrm{mg}, 90 \%$ yield, 93\% ee) was obtained according to the general procedure from 1-cyclopropylethanone (46 $\mathrm{mg}, 0.55 \mathrm{mmol})$ and $p$-anisidine (62 mg, $0.5 \mathrm{mmol})$ in $20 \mathrm{~h}$; ${ }^{1} \mathrm{H}-\mathrm{NMR}: \delta 0.21-0.31(\mathrm{~m}, 2 \mathrm{H}), 0.43-0.52(\mathrm{~m}, 2 \mathrm{H}), 0.86-0.95(\mathrm{~m}, 1 \mathrm{H})$, 
$1.20(\mathrm{~d}, J=6.3 \mathrm{~Hz}, 3 \mathrm{H}), 2.82-2.89(\mathrm{~m}, 1 \mathrm{H}), 3.74(\mathrm{~s}, 3 \mathrm{H}), 6.56-6.60(\mathrm{~m}, 2 \mathrm{H}), 6.74-6.78(\mathrm{~m}, 2 \mathrm{H}) ;{ }^{13} \mathrm{C}-$ NMR: $\delta 2.9,3.6,18.4,20.7,54.2,56.2,115.2,115.5,142.6,152.3 ;$ HRMS for $\mathrm{C}_{12} \mathrm{H}_{18} \mathrm{NO}[\mathrm{M}+\mathrm{H}]^{+}: \mathrm{m} / \mathrm{z}$ Calcd: 192.1388; Found: 192.1381; HPLC (Chiralcel OB-H, hexane:isopropanol = 99:1, flow rate $0.5 \mathrm{~mL} / \mathrm{min}, \lambda=254 \mathrm{~nm}$ ): $\mathrm{t}_{\mathrm{R}}=18.4 \mathrm{~min}$ (major), $\mathrm{t}_{\mathrm{R}}=24.4 \mathrm{~min}$ (minor).

$\mathrm{N}$-(Hex-5-en-2-yl)-4-methoxyaniline (5i) [28,33]. The product (82 $\mathrm{mg}, 80 \%$ yield, 92\% ee) was obtained according to the general procedure from hex-5-en-2-one $(54 \mathrm{mg}, 0.55 \mathrm{mmol})$ and $p$-anisidine (62 mg, $0.5 \mathrm{mmol})$ in $20 \mathrm{~h}$; ${ }^{1} \mathrm{H}-\mathrm{NMR}: \delta 1.15(\mathrm{~d}, J=6.3 \mathrm{~Hz}, 3 \mathrm{H}), 1.38-1.47(\mathrm{~m}, 1 \mathrm{H}), 1.54-1.63$ (m, $1 \mathrm{H}), 2.05-2.11(\mathrm{~m}, 2 \mathrm{H}), 3.10$ (brs, $1 \mathrm{H}), 3.33$ (sextet, $J=6.3 \mathrm{~Hz}, 1 \mathrm{H}), 3.67(\mathrm{~s}, 3 \mathrm{H}), 4.88-4.92(\mathrm{~m}, 1 \mathrm{H})$, $4.96(\mathrm{dq}, J=17.0,1.7 \mathrm{~Hz}, 1 \mathrm{H}), 5.76$ (ddt, $J=17.0,10.3,6.7 \mathrm{~Hz}, 1 \mathrm{H}), 6.46-6.50(\mathrm{~m}, 2 \mathrm{H}), 6.68-6.72$ (m, 2H); ${ }^{13} \mathrm{C}-\mathrm{NMR}: \delta 21.2,30.9,36.7,49.4,56.2,115.1,115.2,115.4,138.9,142.3,152.3$; HRMS for $\mathrm{C}_{13} \mathrm{H}_{20} \mathrm{NO} \quad[\mathrm{M}+\mathrm{H}]^{+}: \mathrm{m} / \mathrm{z}$ Calcd: 206.1545; Found: 206.1547; HPLC (Chiralcel OB-H, hexane:isopropanol $=99: 1$, flow rate $1.0 \mathrm{~mL} / \mathrm{min}, \lambda=254 \mathrm{~nm}$ ): $t_{R}=13.4 \mathrm{~min}$ (major), $t_{R}=15.8 \mathrm{~min}$ (minor).

4-Methoxy-N-(6-methylhept-5-en-2-yl)aniline (5j) [39]. The product (104 mg, 89\% yield, 95\% ee) was obtained according to the general procedure from 6-methylhept-5-en-2-one (69 $\mathrm{mg}, 0.55 \mathrm{mmol})$ and $p$ anisidine $(62 \mathrm{mg}, 0.5 \mathrm{mmol})$ in $20 \mathrm{~h}$; ${ }^{1} \mathrm{H}-\mathrm{NMR}: \delta 1.16(\mathrm{~d}, J=6.3 \mathrm{~Hz}, 3 \mathrm{H}), 1.39-1.48(\mathrm{~m}, 1 \mathrm{H})$, $1.59(\mathrm{~s}, 3 \mathrm{H}), 1.54-1.63(\mathrm{~m}, 1 \mathrm{H}), 1.69(\mathrm{~d}, J=0.8 \mathrm{~Hz}, 3 \mathrm{H}), 2.05-2.10(\mathrm{~m}, 2 \mathrm{H}), 3.37$ (sextet, $J=6.3 \mathrm{~Hz}$, $1 \mathrm{H}), 3.74(\mathrm{~s}, 3 \mathrm{H}), 5.10-5.14(\mathrm{~m}, 1 \mathrm{H}), 6.53-6.57(\mathrm{~m}, 2 \mathrm{H}), 6.75-6.79(\mathrm{~m}, 2 \mathrm{H}) ;{ }^{13} \mathrm{C}-\mathrm{NMR}: \delta 18.1,21.2$, $25.1,26.1,37.6,49.5,56.2,115.1,115.3,124.5,132.4,142.5,152.3$; HRMS for $\mathrm{C}_{15} \mathrm{H}_{24} \mathrm{NO}[\mathrm{M}+\mathrm{H}]^{+}$: m/z Calcd: 234.1858; Found: 234.1865; HPLC (Chiralcel OB-H, hexane:isopropanol = 99:1, flow rate $0.5 \mathrm{~mL} / \mathrm{min}, \lambda=254 \mathrm{~nm}$ ): $\mathrm{t}_{\mathrm{R}}=21.6 \mathrm{~min}$ (major), $\mathrm{t}_{\mathrm{R}}=26.9 \mathrm{~min}$ (minor).

$\mathrm{N}$-[4-(2H-1,3-benzodioxol-5-yl)butan-2-yl]-4-methoxyaniline (5k). The product (127 $\mathrm{mg}, 85 \%$ yield, $93 \%$ ee) was obtained according to the general procedure from 4-benzo[1,3]dioxol-5-yl-butan-2-one (106 mg, $0.55 \mathrm{mmol})$ and $p$-anisidine (62 mg, $0.5 \mathrm{mmol})$ in $20 \mathrm{~h} ;{ }^{1} \mathrm{H}-\mathrm{NMR}: \delta 1.18(\mathrm{~d}, J=6.4 \mathrm{~Hz}, 3 \mathrm{H})$, $1.65-1.74(\mathrm{~m}, 1 \mathrm{H}), 1.78-1.87(\mathrm{~m}, 1 \mathrm{H}), 2.64(\mathrm{t}, J=7.9 \mathrm{~Hz}, 2 \mathrm{H}), 3.36-3.41(\mathrm{~m}, 1 \mathrm{H}), 3.75(\mathrm{~s}, 3 \mathrm{H}), 5.92$ $(\mathrm{s}, 2 \mathrm{H}), 6.53(\mathrm{~d}, J=8.5 \mathrm{~Hz}, 2 \mathrm{H}), 6.62(\mathrm{~d}, J=7.8 \mathrm{~Hz}, 1 \mathrm{H}), 6.67(\mathrm{~d}, J=1.6 \mathrm{~Hz}, 1 \mathrm{H}), 6.72(\mathrm{~d}, J=7.8 \mathrm{~Hz}$, 1H), 6.75-6.77 (m, 2H); ${ }^{13} \mathrm{C}-\mathrm{NMR}: \delta 21.3,32.6,39.5,49.3,56.2,101.2,108.6,109.3,115.2,115.4$, 121.6, 136.4, 142.1, 146.0, 148.0, 152.3; HRMS for $\mathrm{C}_{18} \mathrm{H}_{22} \mathrm{NO}_{3}[\mathrm{M}+\mathrm{H}]^{+}: \mathrm{m} / \mathrm{z}$ Calcd: 300.1599; Found: 300.1590; HPLC (Chiralcel OD-H, hexane:isopropanol $=98: 2$, flow rate $1 \mathrm{~mL} / \mathrm{min}$, $\lambda=254 \mathrm{~nm}): \mathrm{t}_{\mathrm{R}}=28.7 \mathrm{~min}($ major $), \mathrm{t}_{\mathrm{R}}=38.6 \mathrm{~min}$ (minor).

3-Methoxy-N-(4-methylpentan-2-yl)aniline (6a). The product $(75 \mathrm{mg}, 72 \%$ yield, $80 \%$ ee) was obtained according the general procedure from 4-methyl-2-pentanone (55 $\mathrm{mg}, 0.55 \mathrm{mmol}$ ) and $\mathrm{m}$ anisidine (62 mg, $0.5 \mathrm{mmol})$ in $20 \mathrm{~h}$; ${ }^{1} \mathrm{H}-\mathrm{NMR}$ : $\delta 0.90(\mathrm{~d}, J=6.6 \mathrm{~Hz}, 3 \mathrm{H}), 0.94(\mathrm{~d}, J=6.6 \mathrm{~Hz}, 3 \mathrm{H})$, $1.15(\mathrm{~d}, J=6.8 \mathrm{~Hz}, 3 \mathrm{H}), 1.25(\mathrm{dt}, J=13.6,6.8 \mathrm{~Hz}, 1 \mathrm{H}), 1.46(\mathrm{dt}, J=13.6,6.9 \mathrm{~Hz}, 1 \mathrm{H}), 1.71-1.79$ (m, $1 \mathrm{H}), 3.40$ (brs, $1 \mathrm{H}), 3.46-3.54(\mathrm{~m}, 1 \mathrm{H}), 3.76(\mathrm{~s}, 3 \mathrm{H}), 6.13(\mathrm{t}, J=2.2 \mathrm{~Hz}, 1 \mathrm{H}), 6.21(\mathrm{dd}, J=8.1,2.2 \mathrm{~Hz}$, 2H), $7.06(\mathrm{t}, J=8.1 \mathrm{~Hz}, 1 \mathrm{H}) ;{ }^{13} \mathrm{C}-\mathrm{NMR}: \delta 21.5,23.0,23.4,25.5,47.0,47.3,55.5,99.3,102.2,106.7$, 130.4, 149.5, 161.3; HRMS for $\mathrm{C}_{13} \mathrm{H}_{22} \mathrm{NO}[\mathrm{M}+\mathrm{H}]^{+}: \mathrm{m} / \mathrm{z}$ Calcd: 208.1701; Found: 208.1711; HPLC 
(Chiralcel OD-H, hexane:isopropanol $=98: 2$, flow rate $0.5 \mathrm{~mL} / \mathrm{min}, \lambda=254 \mathrm{~nm}$ ): $\mathrm{t}_{\mathrm{R}}=19.9 \min$ (minor), $\mathrm{t}_{\mathrm{R}}=21.9 \mathrm{~min}$ (major).

3-Methoxy-N-(3-methylpentan-2-yl)aniline (6b). Mixture of diastereoisomers 54:46. The product (85 mg, 82\% yield, 96\% ee) was obtained according the general procedure from 3-methylpentan-2-one (55 mg, $0.55 \mathrm{mmol})$ and $m$-anisidine $(62 \mathrm{mg}, 0.5 \mathrm{mmol})$ in $20 \mathrm{~h} ;{ }^{1} \mathrm{H}-\mathrm{NMR}: \delta 0.86(\mathrm{~d}, J=6.8 \mathrm{~Hz}$, $1.5 \mathrm{H}), 0.89(\mathrm{t}, J=7.4 \mathrm{~Hz}, 1.5 \mathrm{H}), 0.82-0.96(\mathrm{~m}, 3 \mathrm{H}), 1.06(\mathrm{~d}, J=6.5 \mathrm{~Hz}, 1.5 \mathrm{H}), 1.10(\mathrm{~d}, J=6.5 \mathrm{~Hz}$, 1.5H), 1.13-1.23 (m, 1H), 1.44-1.65 (m, 2H), 3.40-3.45 (m, 1H), 3.53 (brs, 1H), $3.76(\mathrm{~s}, 3 \mathrm{H}), 6.13$ (t, $J=2.2 \mathrm{~Hz}, 1 \mathrm{H}), 6.18-6.23(\mathrm{~m}, 2 \mathrm{H}), 7.03-7.07(\mathrm{~m}, 1 \mathrm{H}) ;{ }^{13} \mathrm{C}-\mathrm{NMR}: \delta 12.3(6), 12.4(3), 14.2,15.7,16.3$, 17.7, 25.3, 26.9, 38.9, 39.6, 52.1, 52.7, 55.5, 99.2, 99.3, 101.9, 102.0, 106.6,(3), 106.6(7), 130.4, 149.5, 149.7, 161.3; HRMS for $\mathrm{C}_{13} \mathrm{H}_{22} \mathrm{NO}[\mathrm{M}+\mathrm{H}]^{+}: \mathrm{m} / \mathrm{z}$ Calcd: 208.1701; Found: 208.1700; HPLC (Chiralcel OD-H, hexane:isopropanol $=99.5: 0.5$, flow rate $0.5 \mathrm{~mL} / \mathrm{min}, \lambda=254 \mathrm{~nm}): \mathrm{t}_{\mathrm{R}}=46.7 \mathrm{~min}(\mathrm{~d} 1$, major $), t_{R}=50.3 \min (d 2$, major $), t_{R}=55.6(d 1$, minor $), t_{R}=58.2(d 2$, minor $)$.

3-Methoxy-N-(3-methylbutan-2-yl)aniline (6c). The product ( $83 \mathrm{mg}, 86 \%$ yield, $90 \%$ ee) was obtained according the general procedure from 3-methylbutan-2-one (47 $\mathrm{mg}, 0.55 \mathrm{mmol})$ and $\mathrm{m}$-anisidine (62 $\mathrm{mg}$, $0.5 \mathrm{mmol})$ in $20 \mathrm{~h}$; ${ }^{1} \mathrm{H}-\mathrm{NMR}: \delta 0.90(\mathrm{~d}, J=6.8 \mathrm{~Hz}, 3 \mathrm{H}), 0.96(\mathrm{~d}, J=8.0 \mathrm{~Hz}, 3 \mathrm{H}), 1.09(\mathrm{~d}, J=6.5 \mathrm{~Hz}$, $3 \mathrm{H}), 1.80-1.88(\mathrm{~m}, 1 \mathrm{H}), 3.28-3.42(\mathrm{~m}, 1 \mathrm{H}), 3.52$ (brs, $1 \mathrm{H}), 3.76(\mathrm{~s}, 3 \mathrm{H}), 6.13(\mathrm{t}, J=2.3 \mathrm{~Hz}, 1 \mathrm{H})$, 6.18-6.23 (m, 2H), $7.05(\mathrm{t}, J=8.1 \mathrm{~Hz}, 1 \mathrm{H}) ;{ }^{13} \mathrm{C}-\mathrm{NMR}: \delta$ 17.0, 17.9, 19.6, 32.6, 53.8, 55.5, 99.3, 102.0, 106.7, 130.4, 149.6, 161.3; HRMS for $\mathrm{C}_{12} \mathrm{H}_{20} \mathrm{NO}[\mathrm{M}+\mathrm{H}]^{+}: \mathrm{m} / \mathrm{z}$ Calcd: 194.1539; Found: 194.1541; HPLC (Chiralcel OB-H, hexane:isopropanol $=98: 2$, flow rate $0.5 \mathrm{~mL} / \mathrm{min}, \lambda=254 \mathrm{~nm}$ ): $\mathrm{t}_{\mathrm{R}}=10.9 \mathrm{~min}$ (minor), $\mathrm{t}_{\mathrm{R}}=12.9 \min$ (major).

3-Methoxy-N-(pentan-2-yl)aniline (6d). The product (74 mg, 77\% yield, 91\% ee) was obtained according the general procedure from 2-pentanone $(47 \mathrm{mg}, 0.55 \mathrm{mmol})$ and $\mathrm{m}$-anisidine $(62 \mathrm{mg}$, $0.5 \mathrm{mmol})$ in $20 \mathrm{~h}$; ${ }^{1} \mathrm{H}-\mathrm{NMR}: \delta 0.92(\mathrm{t}, J=7.1 \mathrm{~Hz}, 3 \mathrm{H}), 1.16(\mathrm{~d}, J=6.3 \mathrm{~Hz}, 3 \mathrm{H}), 1.36-1.43(\mathrm{~m}, 3 \mathrm{H})$, $1.52-1.57(\mathrm{~m}, 1 \mathrm{H}), 3.41-3.48(\mathrm{~m}, 2 \mathrm{H}), 3.77(\mathrm{~s}, 3 \mathrm{H}), 6.13(\mathrm{t}, J=2.3 \mathrm{~Hz}, 1 \mathrm{H}), 6.19$ (ddd, $J=8.1,2.3$, $0.8 \mathrm{~Hz}, 1 \mathrm{H}), 6.23$ (ddd, $J=8.1,2.3,0.8 \mathrm{~Hz}, 1 \mathrm{H}), 7.06(\mathrm{t}, J=8.1 \mathrm{~Hz}, 1 \mathrm{H}) ;{ }^{13} \mathrm{C}-\mathrm{NMR}: \delta 14.5,19.7$, $21.2,39.8,48.7,55.5,99.5,102.3,106.8,130.4,149.4,161.3$; HRMS for $\mathrm{C}_{13} \mathrm{H}_{22} \mathrm{NO}[\mathrm{M}+\mathrm{H}]^{+}: \mathrm{m} / \mathrm{z}$ Calcd: 194.1539; Found: 194.1540; HPLC (Chiralcel OB-H, hexane:isopropanol $=98: 2$, flow rate $0.5 \mathrm{~mL} / \mathrm{min}, \lambda=254 \mathrm{~nm}$ ): $\mathrm{t}_{\mathrm{R}}=14.4 \mathrm{~min}$ (minor), $\mathrm{t}_{\mathrm{R}}=16.0 \mathrm{~min}$ (major).

$N$-(Hexan-2-yl)-3-methoxyaniline (6e) [40]. The product (88 $\mathrm{mg}, 85 \%$ yield, 92\% ee) was obtained according the general procedure from 2-hexanone $(55 \mathrm{mg}, 0.55 \mathrm{mmol})$ and $\mathrm{m}$-anisidine (62 $\mathrm{mg}$, $0.5 \mathrm{mmol})$ in $20 \mathrm{~h} ;{ }^{1} \mathrm{H}-\mathrm{NMR}: \delta 0.90(\mathrm{t}, J=7.1 \mathrm{~Hz}, 3 \mathrm{H}), 1.16(\mathrm{~d}, J=6.3 \mathrm{~Hz}, 3 \mathrm{H}), 1.30-1.45(\mathrm{~m}, 5 \mathrm{H})$, $1.52-1.58$ (m, 1H), 3.43 (sextet, $J=6.3 \mathrm{~Hz}, 1 \mathrm{H}), 3.46$ (brs, $1 \mathrm{H}), 3.77$ (s, 3H), 6.13 (t, $J=2.3 \mathrm{~Hz}, 1 \mathrm{H}$ ), 6.18-6.24 (m, 2H), $7.06(\mathrm{t}, J=8.1 \mathrm{~Hz}, 1 \mathrm{H}) ;{ }^{13} \mathrm{C}-\mathrm{NMR}: \delta 14.5,21.2,23.2,28.8,37.3,49.0,55.5,99.5$, 102.3, 106.8, 130.4, 149.3, 161.3; HRMS for $\mathrm{C}_{13} \mathrm{H}_{22} \mathrm{NO}[\mathrm{M}+\mathrm{H}]^{+}: \mathrm{m} / \mathrm{z}$ Calcd: 208.1696; Found: 208.1696; HPLC (Chiralcel OB-H, hexane:isopropanol $=98: 2$, flow rate $0.5 \mathrm{~mL} / \mathrm{min}, \lambda=254 \mathrm{~nm}$ ): $\mathrm{t}_{\mathrm{R}}=13.5 \mathrm{~min}$ (minor), $\mathrm{t}_{\mathrm{R}}=15.5 \mathrm{~min}$ (major). 
$\mathrm{N}$-(Heptan-3-yl)-3-methoxyaniline (6f). The product (90 $\mathrm{mg}, 81 \%$ yield, 61\% ee) was obtained according the general procedure from 3-heptanone $(63 \mathrm{mg}, 0.55 \mathrm{mmol})$ and $\mathrm{m}$-anisidine $(62 \mathrm{mg}$, $0.5 \mathrm{mmol})$ in $20 \mathrm{~h}$; ${ }^{1} \mathrm{H}-\mathrm{NMR}: \delta 0.89(\mathrm{t}, J=7.0 \mathrm{~Hz}, 3 \mathrm{H}), 0.91(\mathrm{t}, J=7.4 \mathrm{~Hz}, 3 \mathrm{H}), 1.24-1.63(\mathrm{~m}, 8 \mathrm{H})$, 3.25 (quintet, $J=6.0 \mathrm{~Hz}, 1 \mathrm{H}), 3.45$ (brs, $1 \mathrm{H}), 3.77(\mathrm{~s}, 3 \mathrm{H}), 6.12(\mathrm{t}, J=2.2 \mathrm{~Hz}, 1 \mathrm{H}), 6.17-6.22(\mathrm{~m}, 2 \mathrm{H})$, $7.05(\mathrm{t}, J=8.1 \mathrm{~Hz}, 1 \mathrm{H}) ;{ }^{13} \mathrm{C}-\mathrm{NMR}: \delta 10.5,14.5,23.3,27.7,28.6,34.5,54.5,55.5,99.1,101.8,106.5$, 130.4, 150.0, 161.3; HRMS for $\mathrm{C}_{14} \mathrm{H}_{24} \mathrm{NO}[\mathrm{M}+\mathrm{H}]^{+}: \mathrm{m} / \mathrm{z}$ Calcd: 222.1852; Found: 222.1851; HPLC (Chiralcel OB-H, hexane:isopropanol $=98: 2$, flow rate $0.5 \mathrm{~mL} / \mathrm{min}, \lambda=254 \mathrm{~nm}$ ): $\mathrm{t}_{\mathrm{R}}=12.6 \mathrm{~min}$ (minor), $t_{\mathrm{R}}=15.9 \min$ (major).

3-Methoxy-N-(octan-3-yl)aniline (6g). The product (98 $\mathrm{mg}, 83 \%$ yield, 64\% ee) was obtained according the general procedure from 3 -octanone $(71 \mathrm{mg}, 0.55 \mathrm{mmol})$ and $\mathrm{m}$-anisidine $(62 \mathrm{mg}$, $0.5 \mathrm{mmol})$ in $20 \mathrm{~h}$; ${ }^{1} \mathrm{H}-\mathrm{NMR}$ : $\delta 0.87(\mathrm{t}, J=7.0 \mathrm{~Hz}, 3 \mathrm{H}), 0.91(\mathrm{t}, J=7.5 \mathrm{~Hz}, 3 \mathrm{H}), 1.25-1.61(\mathrm{~m}, 10 \mathrm{H})$, $3.22-3.28(\mathrm{~m}, 1 \mathrm{H}), 3.44$ (brs, $1 \mathrm{H}), 3.77(\mathrm{~s}, 3 \mathrm{H}), 6.12$ (t, $J=2.2 \mathrm{~Hz}, 1 \mathrm{H}), 6.17-6.22(\mathrm{~m}, 2 \mathrm{H}), 7.05$ $(\mathrm{t}, J=8.1 \mathrm{~Hz}, 1 \mathrm{H}) ;{ }^{13} \mathrm{C}-\mathrm{NMR}: \delta 10.5,14.5,23.1,26.1,27.7,32.4,34.8,54.5,55.5,99.1,101.8,106.5$, 130.4, 150.0, 161.3; HRMS for $\mathrm{C}_{15} \mathrm{H}_{26} \mathrm{NO}[\mathrm{M}+\mathrm{H}]^{+}: \mathrm{m} / \mathrm{z}$ Calcd: 236.2009; Found: 236.2008; HPLC (Chiralcel OJ, hexane:isopropanol $=99.5: 0.5$, flow rate $0.5 \mathrm{~mL} / \mathrm{min}, \lambda=254 \mathrm{~nm}$ ): $\mathrm{t}_{\mathrm{R}}=21.2 \mathrm{~min}$ (major), $\mathrm{t}_{\mathrm{R}}=25.2 \mathrm{~min}$ (minor).

1-(2,6-Dimethylhept-5-enyl)-3-methoxybenzene (6h) [40]. The product (78 $\mathrm{mg}, 67 \%$ yield, 82\% ee) was obtained according the general procedure from 6-methylhept-5-en-2-one (69 $\mathrm{mg}, 0.55 \mathrm{mmol})$ and $m$-anisidine (62 mg, $0.5 \mathrm{mmol})$ in $20 \mathrm{~h} ;{ }^{1} \mathrm{H}-\mathrm{NMR}: \delta 1.17(\mathrm{~d}, J=6.3 \mathrm{~Hz}, 3 \mathrm{H}), 1.43-1.50(\mathrm{~m}, 1 \mathrm{H})$, 1.55-1.64 (m, 1H), 1.59 (s, 3H), 1.69 (d, $J=0.8 \mathrm{~Hz}, 3 \mathrm{H}), 2.07$ (q, $J=7.4 \mathrm{~Hz}, 2 \mathrm{H}$ ), 3.44 (sextet, $J=6.3 \mathrm{~Hz}, 1 \mathrm{H}), 3.51(\mathrm{brs}, 1 \mathrm{H}), 3.76(\mathrm{~s}, 3 \mathrm{H}), 5.10-5.14(\mathrm{~m}, 1 \mathrm{H}), 6.13(\mathrm{t}, J=2.2 \mathrm{~Hz}, 1 \mathrm{H}), 6.19(\mathrm{dd}$, $J=8.0,2.2 \mathrm{~Hz}, 1 \mathrm{H}), 6.23(\mathrm{dd}, J=8.0,2.2 \mathrm{~Hz}, 1 \mathrm{H}), 7.05(\mathrm{t}, J=8.0 \mathrm{~Hz}, 1 \mathrm{H}) ;{ }^{13} \mathrm{C}-\mathrm{NMR}: \delta 18.1$, 21.2, 25.1, 26.1, 37.5, 48.6, 55.5, 99.4, 102.3, 106.8, 124.4, 130.4, 132.5, 149.4, 161.3; HRMS for $\mathrm{C}_{15} \mathrm{H}_{24} \mathrm{NO} \quad[\mathrm{M}+\mathrm{H}]^{+}: \quad \mathrm{m} / \mathrm{z}$ Calcd: 234.1858; Found: 234.1857; HPLC (Chiralcel OD-H, hexane:isopropanol $=98: 2$, flow rate $0.5 \mathrm{~mL} / \mathrm{min}, \lambda=254 \mathrm{~nm}$ ): $\mathrm{t}_{\mathrm{R}}=20.5 \mathrm{~min}$ (minor), $\mathrm{t}_{\mathrm{R}}=21.6 \mathrm{~min}$ (major).

$\mathrm{N}$-(1-Cyclopropylethyl)-3-methoxyaniline (6i) [40]. The product (59 $\mathrm{mg}, 62 \%$ yield, 82\% ee) was obtained according the general procedure from 1-cyclopropylethanone (46 $\mathrm{mg}, 0.55 \mathrm{mmol}$ ) and $\mathrm{m}$ anisidine (62 mg, $0.5 \mathrm{mmol})$ in $20 \mathrm{~h} ;{ }^{1} \mathrm{H}-\mathrm{NMR}: \delta 0.23-0.34(\mathrm{~m}, 2 \mathrm{H}), 0.43-0.53(\mathrm{~m}, 2 \mathrm{H}), 0.89-0.96(\mathrm{~m}$, $1 \mathrm{H}), 1.22(\mathrm{~d}, J=6.3 \mathrm{~Hz}, 3 \mathrm{H}), 2.92-2.99(\mathrm{~m}, 1 \mathrm{H}), 3.76(\mathrm{~s}, 3 \mathrm{H}), 6.15(\mathrm{t}, J=2.2 \mathrm{~Hz}, 1 \mathrm{H}), 6.20-6.25(\mathrm{~m}$, 2H), $7.05(\mathrm{t}, J=8.1 \mathrm{~Hz}, 1 \mathrm{H}) ;{ }^{13} \mathrm{C}-\mathrm{NMR}: \delta 3.0,3.5,18.2,20.6,53.0,55.5,99.6,102.5,106.9,130.3$, 149.5, 161.2; HRMS for $\mathrm{C}_{12} \mathrm{H}_{18} \mathrm{NO}[\mathrm{M}+\mathrm{H}]^{+}: \mathrm{m} / \mathrm{z}$ Calcd: 192.1383; Found: 192.1386; HPLC (Chiralcel OD-H, hexane:isopropanol $=99.5: 0.5$, flow rate $1 \mathrm{~mL} / \mathrm{min}, \lambda=254 \mathrm{~nm}$ ): $\mathrm{t}_{\mathrm{R}}=37.0 \mathrm{~min}$ (major), $\mathrm{t}_{\mathrm{R}}=38.0 \mathrm{~min}$ (minor).

$N-(4-(B e n z o[d][1,3]$ dioxol-5-yl)butan-2-yl)-3-methoxyaniline $(\mathbf{6 j})$. The product (120 mg, 80\% yield, $91 \%$ ee) was obtained according the general procedure from 4-benzo[1,3]dioxol-5-yl-butan-2-one (106 mg, $0.55 \mathrm{mmol}$ ) and $\mathrm{m}$-anisidine (62 mg, $0.5 \mathrm{mmol})$ in $20 \mathrm{~h} ;{ }^{1} \mathrm{H}-\mathrm{NMR}: \delta 1.19(\mathrm{~d}, J=6.3 \mathrm{~Hz}$, $3 \mathrm{H}), 1.66-1.75(\mathrm{~m}, 1 \mathrm{H}), 1.77-1.86(\mathrm{~m}, 1 \mathrm{H}), 2.63(\mathrm{t}, J=7.8 \mathrm{~Hz}, 2 \mathrm{H}), 3.45$ (sextet, $J=6.3 \mathrm{~Hz}$, 
$1 \mathrm{H}), 5.91(\mathrm{~s}, 2 \mathrm{H}), 6.09(\mathrm{t}, J=2.2 \mathrm{~Hz}, 1 \mathrm{H}), 6.14-6.17(\mathrm{~m}, 1 \mathrm{H}), 6.22-6.25(\mathrm{~m}, 1 \mathrm{H}), 6.62(\mathrm{dd}$, $J=7.8,1.6 \mathrm{~Hz}, 1 \mathrm{H}), 6.67(\mathrm{~d}, J=1.6 \mathrm{~Hz}, 1 \mathrm{H}), 6.72(\mathrm{~d}, J=7.8 \mathrm{~Hz}, 1 \mathrm{H}), 7.05(\mathrm{t}, J=8.1 \mathrm{~Hz}, 1 \mathrm{H}) ;{ }^{13} \mathrm{C}-$ NMR: $\delta 21.3,32.6,39.5,48.2,55.5,99.4,101.2,102.4,106.7,108.6,109.3,121.5,130.4,136.2$, 146.0, 148.0, 149.3, 161.3; HRMS for $\mathrm{C}_{18} \mathrm{H}_{22} \mathrm{NO}_{3}[\mathrm{M}+\mathrm{H}]^{+}: \mathrm{m} / \mathrm{z}$ Calcd: 300.1588; Found: 300.1600; HPLC (Chiralcel OD-H, hexane:isopropanol $=90: 10$ flow rate $1 \mathrm{~mL} / \mathrm{min}, \lambda=254 \mathrm{~nm}$ ): $\mathrm{t}_{\mathrm{R}}=25.5 \mathrm{~min}$ (major), $\mathrm{t}_{\mathrm{R}}=29.2 \mathrm{~min}$ (minor).

$\mathrm{N}$-(4-Methylpentan-2-yl)aniline (7a) [24,46]. The product (71 $\mathrm{mg}, 80 \%$ yield, $88 \%$ ee) was obtained according to the general procedure from 4-methylpentan-2-one $(55 \mathrm{mg}, 0.55 \mathrm{mmol})$ and aniline (47 mg, $0.5 \mathrm{mmol})$ in $20 \mathrm{~h}$; ${ }^{1} \mathrm{H}-\mathrm{NMR}: \delta 0.91$ (d, $\left.J=6.6 \mathrm{~Hz}, 3 \mathrm{H}\right), 0.94(\mathrm{~d}, J=6.6 \mathrm{~Hz}, 3 \mathrm{H}), 1.16(\mathrm{~d}$, $J=6.3 \mathrm{~Hz}, 3 \mathrm{H}), 1.26(\mathrm{dt}, J=13.7 \mathrm{~Hz}, 6.9 \mathrm{~Hz}, 1 \mathrm{H}), 1.47(\mathrm{dt}, J=13.7 \mathrm{~Hz}, 6.9 \mathrm{~Hz}, 1 \mathrm{H}), 1.70-1.80$ (m, $1 \mathrm{H}), 3.39$ (brs, $1 \mathrm{H}), 3.47-3.57(\mathrm{~m}, 1 \mathrm{H}), 6.56-6.59$ (m, 2H), 6.65 (tt, $J=7.3,1.0 \mathrm{~Hz}, 1 \mathrm{H}), 7.13-7.20$ (m, $2 \mathrm{H}){ }^{13} \mathrm{C}-\mathrm{NMR}: \delta 21.5,23.1,23.4,25.5,46.9,47.4,113.5,117.2,129.8,148.2 ;$ HRMS for $\mathrm{C}_{12} \mathrm{H}_{20} \mathrm{~N}$ $[\mathrm{M}+\mathrm{H}]^{+}: \quad \mathrm{m} / \mathrm{z} \quad$ Calcd: 178.1596; Found: 178.1590; HPLC (Chiralcel OB-H, hexane:isopropanol $=99.5: 0.5$, flow rate $0.5 \mathrm{~mL} / \mathrm{min}, \lambda=254 \mathrm{~nm}$ ): $\mathrm{t}_{\mathrm{R}}=7.7$ min (minor), $\mathrm{t}_{\mathrm{R}}=8.6 \min$ (major).

$N$-(Pentan-2-yl)aniline (7b) [47]. The product (75 mg, 92\% yield, 94\% ee) was obtained according to the general procedure from 2-pentanone $(47 \mathrm{mg}, 0.55 \mathrm{mmol})$ and aniline $(47 \mathrm{mg}, 0.5 \mathrm{mmol})$ in $20 \mathrm{~h}$; ${ }^{1} \mathrm{H}$ - NMR: $\delta 0.93(\mathrm{t}, J=7.1 \mathrm{~Hz}, 3 \mathrm{H}), 1.17(\mathrm{~d}, J=6.2 \mathrm{~Hz}, 3 \mathrm{H}), 1.35-1.46(\mathrm{~m}, 3 \mathrm{H}), 1.50-1.60(\mathrm{~m}$, $1 \mathrm{H}), 3.45$ (brs, 1H), 3.47 (sextet, $J=6.2 \mathrm{~Hz}, 1 \mathrm{H}), 6.55-6.58(\mathrm{~m}, 2 \mathrm{H}), 6.65(\mathrm{tt}, J=7.3,1.0 \mathrm{~Hz}, 1 \mathrm{H})$, 7.13-7.20 (m, 2H); ${ }^{13} \mathrm{C}-\mathrm{NMR}: \delta 14.5,19.7,21.2,39.9,48.6,113.5,117.1,129.7,148.3$; HRMS for $\mathrm{C}_{11} \mathrm{H}_{18} \mathrm{~N} \quad[\mathrm{M}+\mathrm{H}]^{+}: \quad \mathrm{m} / \mathrm{z}$ Calcd: 164.1439; Found: 164.1440; HPLC (Chiralcel OJ, hexane:isopropanol $=99.5: 0.5$, flow rate $0.5 \mathrm{~mL} / \mathrm{min}, \lambda=254 \mathrm{~nm}$ ): $\mathrm{t}_{\mathrm{R}}=28.8$ min (major), $\mathrm{t}_{\mathrm{R}}=34.8 \mathrm{~min}$ (minor). The ee was determined by weighing the HPLC peaks, as the peak corresponding to the minor enantiomer was too small and wide to be integrated.

$\mathrm{N}$-(Hexan-2-yl)aniline (7c) [48]. The product (75 mg, 85\% yield, 95\% ee) was obtained according to the general procedure from 2-hexanone $(55 \mathrm{mg}, 0.55 \mathrm{mmol})$ and aniline $(47 \mathrm{mg}, 0.5 \mathrm{mmol})$ in $20 \mathrm{~h}$; ${ }^{1} \mathrm{H}-\mathrm{NMR}: \delta 0.90(\mathrm{t}, J=7.1 \mathrm{~Hz}, 3 \mathrm{H}), 1.16(\mathrm{~d}, J=6.3 \mathrm{~Hz}, 3 \mathrm{H}), 1.28-1.47(\mathrm{~m}, 5 \mathrm{H}), 1.53-1.56(\mathrm{~m}, 1 \mathrm{H})$, 3.41-3.48 (m, 2H), 6.55-6.58 (m, 2H), $6.65(\mathrm{tt}, J=7.3,1.0 \mathrm{~Hz}, 1 \mathrm{H}), 7.13-7.18(\mathrm{~m}, 2 \mathrm{H})$; ${ }^{13} \mathrm{C}-\mathrm{NMR}: \delta$ 14.5, 21.2, 23.2, 28.8, 37.4, 48.8, 113.5, 117.1, 129.7, 148.1; HRMS for $\mathrm{C}_{12} \mathrm{H}_{20} \mathrm{~N}[\mathrm{M}+\mathrm{H}]^{+}: \mathrm{m} / \mathrm{z}$ Calcd: 178.1596; Found: 178.1590; HPLC (Chiralcel OB-H, hexane:isopropanol $=99.5: 0.5$, flow rate $0.25 \mathrm{~mL} / \mathrm{min}, \lambda=254 \mathrm{~nm}$ ): $\mathrm{t}_{\mathrm{R}}=18.2 \mathrm{~min}$ (minor), $\mathrm{t}_{\mathrm{R}}=19.1 \mathrm{~min}$ (major).

$\mathrm{N}$-(Heptan-2-yl)aniline (7d) [42,49]. The product (79 $\mathrm{mg}, 83 \%$ yield, 92\% ee) was obtained according to the general procedure from 2-heptanone $(63 \mathrm{mg}, 0.55 \mathrm{mmol})$ and aniline $(47 \mathrm{mg}, 0.5 \mathrm{mmol})$ in $20 \mathrm{~h}$; ${ }^{1} \mathrm{H}-\mathrm{NMR}: \delta 0.88(\mathrm{t}, J=7.0 \mathrm{~Hz}, 3 \mathrm{H}), 1.17(\mathrm{~d}, J=6.3 \mathrm{~Hz}, 3 \mathrm{H}), 1.26-1.46(\mathrm{~m}, 7 \mathrm{H}), 1.53-1.59(\mathrm{~m}, 1 \mathrm{H})$, 3.41 (brs, 1H), 3.44 (sextet, $J=6.3 \mathrm{~Hz}, 1 \mathrm{H}), 6.55-6.58(\mathrm{~m}, 2 \mathrm{H}), 6.65$ (tt, $J=7.3 \mathrm{~Hz}, 1.0 \mathrm{~Hz}, 1 \mathrm{H}$ ), 7.13-7.18 (m, 2H); ${ }^{13} \mathrm{C}-\mathrm{NMR}: \delta$ 14.4, 21.2, 23.1, 26.2, 32.3, 37.6, 48.9, 113.5, 117.1, 129.7, 148.3; HRMS for $\mathrm{C}_{13} \mathrm{H}_{22} \mathrm{~N}[\mathrm{M}+\mathrm{H}]^{+}: \mathrm{m} / \mathrm{z}$ Calcd: 192.1752; Found: 192.1754; HPLC (Chiralcel OB-H, 
hexane:isopropanol $=99.5: 0.5$, flow rate $0.5 \mathrm{~mL} / \mathrm{min}, \lambda=254 \mathrm{~nm}): \mathrm{t}_{\mathrm{R}}=8.8 \mathrm{~min}($ minor $), \mathrm{t}_{\mathrm{R}}=9.7 \mathrm{~min}$ (major).

$N$-(6-Methylhept-5-en-2-yl)aniline (7e). The product (93 $\mathrm{mg}, 91 \%$ yield, 91\% ee) was obtained according to the general procedure from 6-methylhept-5-en-2-one $(69 \mathrm{mg}, 0.55 \mathrm{mmol})$ and aniline (47 mg, $0.5 \mathrm{mmol})$ in $20 \mathrm{~h}$; ${ }^{1} \mathrm{H}-\mathrm{NMR}: \delta 1.17(\mathrm{~d}, J=6.3 \mathrm{~Hz}, 3 \mathrm{H}), 1.42-1.51(\mathrm{~m}, 1 \mathrm{H}), 1.59(\mathrm{~s}, 3 \mathrm{H})$, 1.55-1.64 (m, 1H), 1.69 (d, $J=1.0 \mathrm{~Hz}, 3 \mathrm{H}), 2.08$ (q, $J=7.2 \mathrm{~Hz}, 2 \mathrm{H}), 3.43$ (brs, 1H), 3.46 (sextet, $J=6.3 \mathrm{~Hz}, 1 \mathrm{H}), 5.10-5.14(\mathrm{~m}, 1 \mathrm{H}), 6.55-6.58(\mathrm{~m}, 2 \mathrm{H}), 6.65(\mathrm{tt}, J=7.4,1.0 \mathrm{~Hz}, 1 \mathrm{H}), 7.13-7.17(\mathrm{~m}$, $2 \mathrm{H}) ;{ }^{13} \mathrm{C}$ - NMR: $\delta$ 18.1, 21.2, 25.1, 26.1, 37.6, 48.5, 113.5, 117.2, 124.4, 129.7, 132.4, 148.2; HRMS for $\mathrm{C}_{14} \mathrm{H}_{22} \mathrm{~N} \quad[\mathrm{M}+\mathrm{H}]^{+}: \mathrm{m} / \mathrm{z}$ Calcd: 204.1752; Found: 204.1749; HPLC (Chiralcel OJ, hexane:isopropanol $=99: 1$, flow rate $0.5 \mathrm{~mL} / \mathrm{min}, \lambda=254 \mathrm{~nm}$ ): $t_{R}=15.3 \mathrm{~min}$ (major), $t_{R}=19.4 \mathrm{~min}$ (minor).

$\mathrm{N}$-(1-Cyclopropylethyl)aniline (7f). The product (73 $\mathrm{mg}, 91 \%$ yield, 92\% ee) was obtained according to the general procedure from 1-cyclopropylethanone $(46 \mathrm{mg}, 0.55 \mathrm{mmol}$ ) and aniline (47 $\mathrm{mg}$, $0.5 \mathrm{mmol})$ in $20 \mathrm{~h}$; ${ }^{1} \mathrm{H}-\mathrm{NMR}: \delta 0.22-0.33(\mathrm{~m}, 2 \mathrm{H}), 0.44-0.53(\mathrm{~m}, 2 \mathrm{H}) 0.88-0.97(\mathrm{~m}, 1 \mathrm{H}), 1.22(\mathrm{~d}$, $J=6.5 \mathrm{~Hz}, 3 \mathrm{H}$ ), 2.97 (quintet, $J=6.5 \mathrm{~Hz}, 1 \mathrm{H}), 3.66$ (brs, $1 \mathrm{H}), 6.57-6.60(\mathrm{~m}, 2 \mathrm{H}), 6.66(\mathrm{tt}, J=7.3 \mathrm{~Hz}$, $1.0 \mathrm{~Hz}, 1 \mathrm{H}), 7.13-7.18(\mathrm{~m}, 2 \mathrm{H}){ }^{13} \mathrm{C}-\mathrm{NMR}: \delta 3.0,3.5,18.3,20.6,52.9,113.6,117.3,129.6,148.3$; HRMS for $\mathrm{C}_{11} \mathrm{H}_{16} \mathrm{~N}[\mathrm{M}+\mathrm{H}]^{+}: \mathrm{m} / \mathrm{z}$ Calcd: 162.1283; Found: 162.1286; HPLC (Chiralcel OJ, hexane:isopropanol $=99.5: 0.5$, flow rate $0.5 \mathrm{~mL} / \mathrm{min}, \lambda=254 \mathrm{~nm}$ ): $\mathrm{t}_{\mathrm{R}}=32.4$ min (major), $t_{R}=37.3$ min (minor). The ee was determined by weighing the HPLC peaks, as the peak corresponding to the minor enantiomer was too small and wide to be integrated.

$\mathrm{N}$-[4-(2H-1,3-Benzodioxol-5-yl)butan-2-yl]aniline (7g). The product (128 mg, 95\% yield, 91\% ee) was obtained according to the general procedure from 4-(benzo[1,3]dioxol-5-yl-butan-2-one (106 mg, $0.55 \mathrm{mmol}$ ) and aniline (47 mg, $0.5 \mathrm{mmol})$ in $20 \mathrm{~h}$; ${ }^{1} \mathrm{H}-\mathrm{NMR}: \delta 1.20(\mathrm{~d}, J=6.3 \mathrm{~Hz}, 3 \mathrm{H}), 1.67-1.76(\mathrm{~m}$, $1 \mathrm{H}), 1.78-1.87(\mathrm{~m}, 1 \mathrm{H}), 2.64(\mathrm{t}, J=7.8 \mathrm{~Hz}, 2 \mathrm{H}), 3.42$ (brs, $1 \mathrm{H}), 3.47$ (sextet, $J=6.3 \mathrm{~Hz}, 1 \mathrm{H}), 5.91$ (s, $2 \mathrm{H}), 6.52-6.55(\mathrm{~m}, 2 \mathrm{H}), 6.62(\mathrm{dd}, J=7.9,1.7 \mathrm{~Hz}, 1 \mathrm{H}), 6.64-6.68(\mathrm{~m}, 2 \mathrm{H}), 6.72(\mathrm{~d}, J=7.9 \mathrm{~Hz}, 1 \mathrm{H})$, 7.12-7.17 (m, 2H); ${ }^{13} \mathrm{C}-\mathrm{NMR}: \delta 21.3,32.6,39.5,48.2,101.2,108.6,109.3,113.6,117.4,121.5,129.7$, 136.2, 146.0, 147.9, 148.0; HRMS for $\mathrm{C}_{17} \mathrm{H}_{20} \mathrm{NO}_{2}[\mathrm{M}+\mathrm{H}]^{+}: \mathrm{m} / \mathrm{z}$ Calcd: 270.1494; Found: 270.1503; HPLC (Chiralcel OD-H, hexane:isopropanol $=98: 2$, flow rate $1 \mathrm{~mL} / \mathrm{min}, \lambda=254 \mathrm{~nm}$ ): $\mathrm{t}_{\mathrm{R}}=22.4 \mathrm{~min}$ (major), $\mathrm{t}_{\mathrm{R}}=24.8 \mathrm{~min}$ (minor).

N-(4-(Benzo[d][1,3]dioxol-5-yl)butan-2-yl)-4-bromoaniline (7h). The product (122 $\mathrm{mg}, 70 \%$ yield, $84 \%$ ee) was obtained according the general procedure from 4-(benzo[1,3]dioxol-5-yl-butan-2-one (106 mg, $0.55 \mathrm{mmol})$ and 4-bromoaniline $(86 \mathrm{mg}, 0.5 \mathrm{mmol})$ in $30 \mathrm{~h} ;{ }^{1} \mathrm{H}-\mathrm{NMR}: \delta 1.18(\mathrm{~d}, J=6.1 \mathrm{~Hz}$, $3 \mathrm{H}), 1.66-1.84(\mathrm{~m}, 2 \mathrm{H}), 2.62(\mathrm{t}, J=7.5 \mathrm{~Hz}, 2 \mathrm{H}), 3.36-3.43(\mathrm{~m}, 1 \mathrm{H}), 3.43$ (brs, 1H), 5.92 (s, 2H), 6.39 $(\mathrm{d}, J=8.6 \mathrm{~Hz}, 2 \mathrm{H}), 6.60(\mathrm{~d}, J=7.8 \mathrm{~Hz}, 1 \mathrm{H}), 6.65(\mathrm{~s}, 1 \mathrm{H}), 6.72(\mathrm{~d}, J=7.8 \mathrm{~Hz}, 1 \mathrm{H}), 7.21(\mathrm{~d}, J=8.6 \mathrm{~Hz}$, 2H); ${ }^{13} \mathrm{C}-\mathrm{NMR}: \delta 21.1,32.5,39.3,48.2,101.2,108.6,108.7,109.3,115.1,121.5,132.4,136.0,146.1$, 146.9, 148.0; HRMS for $\mathrm{C}_{17} \mathrm{H}_{19}{ }^{79} \mathrm{BrNO}_{2}[\mathrm{M}+\mathrm{H}]^{+}: \mathrm{m} / \mathrm{z}$ Calcd: 348.0599; Found: 348.0592; HPLC (Chiralcel OJ, hexane:isopropanol $=90: 10$, flow rate $1 \mathrm{~mL} / \mathrm{min}, \lambda=254 \mathrm{~nm}$ ): $\mathrm{t}_{\mathrm{R}}=46.8 \mathrm{~min}$ (major), $\mathrm{t}_{\mathrm{R}}=65.6 \mathrm{~min}$ (minor). 


\section{Conclusions}

Together with our previous results $[28,30]$, this paper demonstrates that $\mathrm{Cp} * \operatorname{Ir}$ (diamine)-phosphate is a powerful catalytic system to enable highly efficient DARA of both aromatic and aliphatic ketones. The catalysis is brought about by the cooperative action of the metal and the counteranion, with the former activating $\mathrm{H}_{2}$ whilst the latter ion-pairing with the protonated substrate. Without the counteranion or with mismatched chirality [28] between the anion and the diamine ligand, much reduced enantioselectivities resulted. In this regard, our bifunctional catalysis differs from the original Noyori proposition, in which the diamine ligand provides the second functionality, i.e. the acidic $\mathrm{NH}_{2}$ proton. Whether or not the amino group functions in the current DARA remains to be delineated, however, and this is being investigated in our lab.

\section{Acknowledgements}

We thank AstraZeneca for a studentship to B. Villa-Marcos and Mark Purdie and Allan Pettman for discussions. We also thank the Research Councils UK for a Dorothy Hodgkin Postgraduate Award to C.Q. Li, and we are grateful to Moya McCarron and Jean Ellis for mass spectra analysis and to Pfizer for general support.

\section{References and Notes}

1. Breuer, M.; Ditrich, K.; Habicher, T.; Hauer, B.; Keßeler, M.; Stürmer, R.; Zelinski, T. Industrial methods for the production of optically active intermediates. Angew. Chem. Int. Edit. 2004, 43, 788-824.

2. Polinsky, R.J. Clinical pharmacology of rivastigmine: A new-generation acetylcholinesterase inhibitor for the treatment of Alzheimer's disease. Clin. Ther. 1998, 20, 634-647.

3. Culy, C.R.; Jarvis, B. Repaglinide - A review of its therapeutic use in type 2 diabetes mellitus. Drugs 2001, 61, 1625-1660.

4. Ye, Z.Q.; Lan, R.Z.; Yang, W.M.; Yao, L.F.; Yu, X. Tamsulosin treatment of chronic nonbacterial prostatitis. J. Int. Med. Res. 2008, 36, 244-252.

5. Ma, W.W.; Anderson, J.E.; McKenzie, A.T.; Byrn, S.R.; McLaughlin, J.L.; Hudson, M.S. Tubulosine - An antitumor constituent of pogonopus-speciosus. J. Nat. Prod. 1990, 53, 1009-1014.

6. Bavadekar, S.A.; Ma, G.Y.; Mustafa, S.M.; Moore, B.M.; Miller, D.D.; Feller, D.R. Tethered yohimbine analogs as selective human alpha(2C)-adrenergic receptor ligands. J. Pharmacol. Exp. Ther. 2006, 319, 739-748.

7. Blaser, H.U.; Spindler, F. Enantioselective hydrogenation of $\mathrm{C}=\mathrm{N}$ functions and enamines. In Handbook of Homogeneous Hydrogenation; De Vries, J.G., Elsevier, C.J., Eds.; Wiley-VCH: Weinheim, Germany, 2007; Volume 3, pp. 1193-1214.

8. Trifonova, A.; Diesen, J.S.; Chapman, C.J.; Andersson, P.G. Application of phosphine-oxazoline ligands in Ir-catalyzed asymmetric hydrogenation of acyclic aromatic N-arylimines. Org. Lett. 2004, 6, 3825-3827. 
9. Nolin, K.A.; Ahn, R.W.; Toste, F.D. Enantioselective reduction of imines catalyzed by a rhenium(V)-oxo complex. J. Am. Chem. Soc. 2005, 127, 12462-12463.

10. Moessner, C.; Bolm, C. Diphenylphosphanylsulfoximines as ligands in iridium-catalyzed asymmetric imine hydrogenations. Angew. Chem.-Int. Ed. 2005, 44, 7564-7567.

11. Yang, Q.; Shang, G.; Gao, W.; Deng, J.; Zhang, X. A highly enantioselective, Pd-TangPhoscatalyzed hydrogenation of N-tosylimines. Angew. Chem.-Int. Ed. 2006, 45, 3832-3835.

12. Zhu, S.F.; Xie, J.B.; Zhang, Y.Z.; Li, S.; Zhou, Q.L. Well-defined chiral spiro iridium/phosphineoxazoline cationic complexes for highly enantioselective hydrogenation of imines at ambient pressure. J. Am. Chem. Soc. 2006, 128, 12886-12891.

13. Reetz, M.T.; Bondarev, O. Mixtures of chiral phosphorous acid diesters and achiral P ligands in the enantio- and diastereoselective hydrogenation of ketimines. Angew. Chem.-Int. Ed. 2007, 46, 4523-4526.

14. Zhou, H.F.; Li, Z.W.; Wang, Z.J.; Wang, T.L.; Xu, L.J.; He, Y.; Fan, Q.H.; Pan, J.; Gu, L.Q.; Chan, A.S.C. Hydrogenation of quinolines using a recyclable phosphine-free chiral cationic ruthenium catalyst: enhancement of catalyst stability and selectivity in an ionic liquid. Angew. Chem.-Int. Edit. 2008, 47, 8464-8467.

15. Shirai, S.Y.; Nara, H.; Kayaki, Y.; Ikariya, T. Remarkable positive effect of silver salts on asymmetric hydrogenation of acyclic imines with $\mathrm{Cp} * \mathrm{Ir}$ complexes bearing chiral $\mathrm{N}$-sulfonylated diamine ligands. Organometallics 2009, 28, 802-809.

16. Tang, W.J.; Xu, L.J.; Fan, Q.H.; Wang, J.; Fan, B.M.; Zhou, Z.Y.; Lam, K.H.; Chan, A.S.C. Asymmetric hydrogenation of quinoxalines with diphosphinite ligands: A practical synthesis of enantioenriched, substituted tetrahydroquinoxalines. Angew. Chem.-Int. Ed. 2009, 48, 9135-9138.

17. Tararov, V.I.; Börner, A. Approaching highly enantioselective reductive amination. Synlett 2005, 203-211.

18. Tripathi, R.P.; Verma, S.S.; Pandey, J.; Tiwari, V.K. Recent development on catalytic reductive amination and applications. Curr. Org. Chem. 2008, 12, 1093-1115.

19. Nugent, T.C.; El-Shazly, M. Chiral amine synthesis - Recent developments and trends for enamide reduction, reductive amination, and imine reduction Adv. Synth. Catal. 2010, doi:10.1002/adsc.200900719.

20. Blaser, H.U.; Buser, H.P.; Jalett, H.P.; Pugin, B.; Spindler, F. Iridium ferrocenyl diphosphine catalyzed enantioselective reductive alkylation of a hindered aniline. Synlett 1999, 867-868.

21. Chi, Y.X.; Zhou, Y.G.; Zhang, X. Highly enantioselective reductive amination of simple aryl ketones catalyzed by Ir-f-Binaphane in the presence of titanium(IV) isopropoxide and iodine. $J$. Org. Chem. 2003, 68, 4120-4122.

22. Kadyrov, R.; Riermeier, T.H. Highly enantioselective hydrogen-transfer reductive amination: Catalytic asymmetric synthesis of primary amines. Angew. Chem.-Int. Ed. 2003, 42, 5472-5474.

23. Williams, G.D.; Pike, R.A.; Wade, C.E.; Wills, M. A one-pot process for the enantioselective synthesis of amines via reductive amination under transfer hydrogenation conditions. Org. Lett. 2003, 5, 4227-4230. 
24. Rubio-Pérez, L.; Pérez-Flores, F.J.; Sharma, P.; Velasco, L.; Cabrera, A. Stable preformed chiral palladium catalysts for the one-pot asymmetric reductive amination of ketones. Org. Lett. 2009, $11,265-268$.

25. Kadyrov, R.; Riermeier, T.H.; Dingerdissen, U.; Tararov, V.; Börner, A. The first highly enantioselective homogeneously catalyzed asymmetric reductive amination: Synthesis of alpha-Nbenzylamino acids. J. Org. Chem. 2003, 68, 4067-4070.

26. Bunlaksananusorn, T.; Rampf, F. A facile one-pot synthesis of chiral beta-amino esters. Synlett 2005, 2682-2684.

27. Constable, D.J.C.; Dunn, P.J.; Hayler, J.D.; Humphrey, G.R.; Leazer, J.L.; Linderman, R.J.; Lorenz, K.; Manley, J.; Pearlman, B.A.; Wells, A.; Zaks, A.; Zhang, T.Y. Key green chemistry research areas - a perspective from pharmaceutical manufacturers. Green Chem. 2007, 9, 411-420.

28. Li, C.Q.; Wang, C.; Villa-Marcos, B.; Xiao, J.L. Chiral counteranion-aided asymmetric hydrogenation of acyclic imines. J. Am. Chem. Soc. 2008, 130, 14450-14451.

29. Li, C.Q.; Xiao, J.L. Asymmetric hydrogenation of cyclic imines with an ionic Cp*Rh(III) catalyst. J. Am. Chem. Soc. 2008, 130, 13208-13209.

30. Li, C.Q.; Villa-Marcos, B.; Xiao, J.L. Metal-Brønsted acid cooperative catalysis for asymmetric reductive amination. J. Am. Chem. Soc. 2009, 131, 6967-6969.

31. Wang, C.; Li, C.Q.; Wu, X.F.; Pettman, A.; Xiao, J.L. pH-regulated asymmetric transfer hydrogenation of quinolines in water. Angew. Chem.-Int. Ed. 2009, 48, 6524-6528.

32. Klussmann, M. Asymmetric reductive amination by combined Brønsted acid and transition-metal catalysis. Angew. Chem.-Int. Edit. 2009, 48, 7124-7125.

33. Storer, R.I.; Carrera, D.E.; Ni, Y.; MacMillan, D.W.C. Enantioselective organocatalytic reductive amination. J. Am. Chem. Soc. 2006, 128, 84-86.

34. Rueping, M.; Sugiono, E.; Azap, C.; Theissmann, T.; Bolte, M. Enantioselective Brønsted acid catalyzed transfer hydrogenation: Organocatalytic reduction of imines. Org. Lett. 2005, 7, 3781-3783.

35. Hoffmann, S.; Seayad, A.M.; List, B. A powerful Brønsted acid catalyst for the organocatalytic asymmetric transfer hydrogenation of imines. Angew. Chem.-Int. Ed. 2005, 44, 7424-7427.

36. Bullock, R.M. Catalytic ionic hydrogenations. Chem.-Eur. J. 2004, 10, 2366-2374.

37. Guan, H.R.; Iimura, M.; Magee, M.P.; Norton, J.R.; Zhu, G. Ruthenium-catalyzed ionic hydrogenation of iminium cations. Scope and mechanism. J. Am. Chem. Soc. 2005, 127, 7805-7814.

38. Ruano, J.L.G.; Cifuentes, M.M.; Lorente, A.; Ramos, J.H.R. Highly stereoselective reduction of acyclic alpha-sulfinyl ketimines: synthesis of enantiomerically pure beta-aminosulfoxides. Tetrahedron Asymmetry 1999, 10, 4607-4618.

39. Hansen, M.C.; Buchwald, S.L. A method for the asymmetric hydrosilylation of N-aryl imines. Org. Lett. 2000, 2, 713-715.

40. Liu, X.Y.; Che, C.M. Highly enantioselective synthesis of chiral secondary amines by gold(I)/chiral Brønsted acid catalyzed tandem intermolecular hydroamination and transfer hydrogenation reactions. Org. Lett. 2009, 11, 4204-4207. 
41. Schnider, P.; Koch, G.; Prétôt, R.; Wang, G.Z.; Bohnen, F.M.; Krüger, C.; Pfaltz, A. Enantioselective hydrogenation of imines with chiral (phosphanodihydrooxazole)iridium catalysts. Chem.-Eur. J. 1997, 3, 887-892.

42. Cho, B.T.; Chun, Y.S. Enantioselective synthesis of optically-active secondary-amines via asymmetric reduction. Tetrahedron Asymmetry 1992, 3, 1583-1590.

43. Mashima, K.; Abe, T.; Tani, K. The half-sandwich hydride and 16-electron complexes of rhodium and iridium containing (1S,2S)-N-(p-toluenesulfonyl)-1,2-diphenylethylenediamine: Relevant to the asymmetric transfer hydrogenation. Chem. Lett. 1998, 1201-1202.

44. Mashima, K.; Abe, T.; Tani, K. Asymmetric transfer hydrogenation of ketonic substrates catalyzed by (eta(5)-C5Me5)MCl complexes (M = Rh and Ir) of (1S,2S)-N-(p-toluenesulfonyl)1,2-diphenylethylenediamine. Chem. Lett. 1998, 1199-1200.

45. Miyata, O.; Ishikawa, T.; Ueda, M.; Naito, T. Novel domino elimination-rearrangement-addition reaction of N-alkoxy(arylmethyl)amines to N-alkyl arylamines. Synlett 2006, 2219-2222.

46. Sato, S.; Sakamoto, T.; Miyazawa, E.; Kikugawa, Y. One-pot reductive amination of aldehydes and ketones with alpha-picoline-borane in methanol, in water, and in neat conditions. Tetrahedron 2004, 60, 7899-7906.

47. Kato, H.; Shibata, I.; Yasaka, Y.; Tsunoi, S.; Yasuda, M.; Baba, A. The reductive amination of aldehydes and ketones by catalytic use of dibutylchlorotin hydride complex. Chem. Commun. 2006, 4189-4191.

48. Duan, H.F.; Sengupta, S.; Petersen, J.L.; Akhmedov, N.G.; Shi, X.D. Triazole-Au(I) complexes: A new class of catalysts with improved thermal stability and reactivity for intermolecular alkyne hydroamination. J. Am. Chem. Soc. 2009, 131, 12100-12102.

49. Samec, J.S.M.; Bäckvall, J.E. Ruthenium-catalyzed transfer hydrogenation of imines by propan-2ol in benzene. Chem.-Eur. J. 2002, 8, 2955-2961.

Sample Availability: Samples of the compounds are available from the authors.

(C) 2010 by the authors; licensee Molecular Diversity Preservation International, Basel, Switzerland. This article is an open-access article distributed under the terms and conditions of the Creative Commons Attribution license (http://creativecommons.org/licenses/by/3.0/). 